\title{
Properties of NMDA Receptor Channels in Neurons Acutely Isolated from Epileptic (Kindled) Rats
}

\author{
Georg Köhr, ${ }^{a}$ Yves De Koninck, and Istvan Mody \\ Department of Neurology and Neurological Sciences, Stanford University School of Medicine, Stanford, California 94305
}

The hyperexcitability accompanying chronic epileptiform activity may result from long-term alterations of ligand- and voltage-gated channels. Previous studies have indicated that NMDA responses and other electrophysiological characteristics of dentate gyrus granule cells are profoundly altered following chronic epilepsy (kindling). We have now investigated channels activated by NMDA using whole-cell patchclamp and cell-attached single-channel recordings in granule cells acutely isolated from control and epileptic (kindled) rats. In control neurons, the amplitude of whole-cell NMDA currents was not sensitive to the presence of an intracellular ATP regeneration system, whereas NMDA currents in kindled cells showed a great variability, with larger amplitudes consistently recorded in the presence of intracellular highenergy phosphates. The ratio of peak to steady-state NMDA current (desensitization) was comparable $(\approx 51 \%)$ in control and kindled neurons. Single-channel conductance determined from fluctuation analysis of whole-cell NMDA currents ranged between 21 and $35 \mathrm{pS}$ in control and between 17 and 37 pS in kindled cells. Whole-cell NMDA channel noise power spectra yielded a single normal distribution of long channel lifetimes (mean, $4.3 \mathrm{msec}$ ) in control neurons, and the sum of two normal distributions (means, 4.6 and 7.1 msec) in kindled cells. The voltage-dependent $\mathbf{M g}^{2+}$ block of NMDA channels was altered following kindling. From curves fitted to voltage-ramp-evoked currents in the presence of NMDA, the calculated affinity for $\mathrm{Mg}^{2+}$ of kindled channels at $0 \mathrm{mV}$ was lower $(12 \mathrm{~mm}$ ) than that of controls (1.7 $\mathrm{mm}$ ). Cell-attached recordings in the absence of $\mathrm{Mg}^{2+}$ have substantiated the lack of effect of kindling on singlechannel conductance $(\approx 50 \mathrm{pS})$, and have demonstrated large increases in mean open times (from $1.26 \mathrm{msec}$ in control to 2.05 msec in kindled), burst lengths (from $1.91 \mathrm{msec}$ to 4.18 msec), and cluster lengths (from $9.11 \mathrm{msec}$ to $20.86 \mathrm{msec}$ ) of NMDA channels in kindled neurons.

In summary, kindling, an NMDA receptor-dependent form of activity-dependent neuronal plasticity induced in vivo, results in lasting modifications in the function of single NMDA

\footnotetext{
Received Dec. 4, 1992; revised Jan. 29, 1993; accepted Feb. 25, 1993.

This work was supported by NINDS Grants NS 12151 and NS 27528 to I.M. G.K. was supported by a Deutsche Forschungsgemcinschaft Postdoctoral Fellowship, and Yves De Koninck was a Fellow of the Canadian MRC. We thank J. T. Palmer for expert technical assistance.

Correspondence should be addressed to Istvan Mody, Ph.D., Department of Anesthesiology and Pain Management, University of Texas Southwestern Medical Center, 5323 Harry Hines Boulevard, Dallas, TX 75235.

a Present address: Zentrum für Molekulare Biologie, I Iniversität Heidelherg, Im Neuenheimer Feld 282, 6900 Heidelberg 1, Germany.

Copyright (C) 1993 Society for Neuroscience $0270-6474 / 93 / 133612-16 \$ 05.00 / 0$
}

receptor channels that can be studied in acutely dissociated neurons. Kindling-induced epilepsy predominantly affects the mean open time, burst, and cluster duration of NMDA channels, their sensitivity to intracellular high-energy phosphates, and their block by $\mathbf{M g}^{2+}$, but not the desensitization or single-channel conductance. Such alterations may reflect a change in the molecular structure of NMDA channels and may underlie the maintenance of the epileptic state.

[Key words: dentate gyrus, epilepsy, excitatory amino acids, hippocampus, kindling, NMDA channels, patch clamp, ion channel regulation, single-channel recording]

In the mammalian brain, the NMDA subtype of glutamate receptors is thought to mediate a wide range of physiological and pathological processes including development, plasticity, epilepsy, excitotoxicity, and neurodegenerative disorders (for review, see Ben-Ari, 1990). Electrophysiolugical evidence is at hand indicating an augmented activation of NMDA receptors in long-term potentiation (LTP) and kindling-induced epilepsy. An increased efficiency of both NMDA and non-NMDA synapses is observed after LTP (Bashir et al., 1991; Xie et al., 1992) and an enhanced NMDA component of synaptic transmission has been found after kindling and in the epileptic human dentate gyrus (Mody and Heinemann, 1987; Gean et al., 1989; Masukawa et al., 1989; Urban et al., 1990).

Thus, much like a positive feedback mechanism, the NMDA receptor-mediated persistent changes in neuronal excitability may include modifications in the structure or function of the NMDA receptors themselves. Akin to other fast ligand-gated ion channels such as the nicotinic ACh receptor (Huganir and

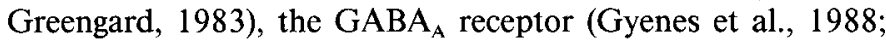
Stelzer et al., 1988), and the kainate subtype of glutamate receptors (Greengard et al., 1991; Wang et al., 1991), accumulating electrophysiological evidence indicates that NMDA receptors appear to be controlled at intracellular sites through redox systems (Aizenman et al., 1989), phosphorylation-related mechanisms (MacDonald et al., 1989), or protein kinase C (Chen and Huang, 1991, 1992). A persistent change in NMDA receptor function may reflect an altered intracellular control mechanism of the channels possibly through changes related to any of the several regulatory sites (for review, see Wong and Kemp, 1991) or may result from structural alterations in the subunit composition of the receptors (Burnashev et al., 1992a,b; Kutsuwada et al., 1992; Monyer et al., 1992; Mori et al., 1992; Yamazaki et al., 1992).

The kindling model of epilepsy is a special case of neuronal plasticity. In this model, a positive feedback related to NMDA receptors has been clearly demonstrated: while NMDA recep- 
tors are of pivotal importance for the progression of epileptiform activity to generalized convulsions during induction of kindling (Peterson et al., 1983; Vezzani et al., 1988; Holmes et al., 1990), compelling biochemical, pharmacological, and electrophysiological evidence indicates an enhanced function of the same receptors following establishment of kindling (Mody and Heinemann, 1987; Gean et al., 1989; Morrisett et al., 1989; Yeh et al., 1989; Martin et al., 1992). An advantage for studying the neuronal plasticity associated with kindling is that kindling can be reliably induced in vivo, but the consequent enduring NMDA receptor-dependent changes in neuronal excitability can be examined in detail in vitro. Moreover, neurons acutely isolated from kindled animals permit the study of chronic alterations in excitability at a biophysical level. For example, we have reported changes in voltage-dependent $\mathrm{Ca}^{2+}$ currents in acutely dissociated granule cells following kindling (Köhr and Mody, 1991a; Köhr et al., 1991).

The present study addresses the possibility of an altered NMDA channel function upon induction of kindling-epilepsy by examining whole-cell and single-channel NMDA responses in acutely dissociated control and kindled neurons. The requirement of NMDA channels for high-energy phosphates, previously investigated by allowing an ATP regeneration system to diffuse from the recording pipette into cultured hippocampal neurons (MacDonald et al., 1989), was studied in kindled granule cells to reveal possible alterations in the phosphorylation state of the channels. Single-channel NMDA conductance and a measure of mean channel lifetime were estimated through the analysis of NMDA current fluctuations in whole-cell recordings. More direct measurements of the complex biophysical properties of single NMDA channels (Gibb and Colquhoun, 1991, 1992) were obtained in cell-attached recordings. Our study unveils for the first time at the single-channel level some of the possible lasting alterations in NMDA channel function that may accompany long-term neuronal plasticity.

Brief reports describing some of the results have appeared elsewhere as abstracts (Köhr and Mody, 1991b, 1992).

\section{Materials and Methods}

Kindling and dissociation of neurons. Procedures for the kindling of male Wistar rats through daily stimulation $(100 \mu \mathrm{A}, 60 \mathrm{~Hz}$ sinewave, for $1 \mathrm{sec}$ ) via the hippocampal commissures, and the dissociation of neurons from hippocampal slices have been previously described in detail (Köhr and Mody, 1991a). All kindled rats $(n=24)$ used in this study satisfied the criterion of full kindling (Racine, 1972). The animals had $30-45$ daily seizures prior to the day of the electrophysiological experiments that were done $24-72 \mathrm{hr}$ after the last stimulation/seizure. Controls $(n=26)$ consisted of both implanted but never stimulated animals $(n=12)$ and unimplanted age-matched animals.

Coronal brain slices prepared from control and kindled rats $(400$ $600 \mathrm{gm}$ ) were maintained at $32^{\circ} \mathrm{C}$ in an artificial cerebrospinal fluid (ACSF) with the following composition (in $\mathrm{mM}$ ): $\mathrm{NaCl}, 126 ; \mathrm{KCl}, 2.5$; $\mathrm{MgCl}_{2}, 2 ; \mathrm{CaCl}_{2}, 2 ; \mathrm{NaH}_{2} \mathrm{PO}_{4}, 1.25 ;$ glucose, $10 ; \mathrm{NaHCO}_{3}, 26 ;$ pyruvic acid, $1 ; \mathrm{pH} 7.35$. The ACSF was constantly bubbled with an $\mathrm{O}_{2} / \mathrm{CO}_{2}$ gas mixture (95\%:5\%). For enzymatic digestion (Mody et al., 1989) single slices were incubated for $30 \mathrm{~min}\left(32^{\circ} \mathrm{C}\right)$ in $2 \mathrm{ml}$ of oxygenated ACSF with $1.5 \mathrm{mg} / \mathrm{ml}$ pronase (protease type XIV, Sigma). The dentate gyrus was microdissected and subsequently triturated using a fire-polished Pasteur pipette in a test tube containing $2 \mathrm{ml}$ of cold $\left(4-8{ }^{\circ} \mathrm{C}\right)$ $N$-2-hydroxyethylpiperazine- $N^{\prime}$-2-ethanesulfonic acid (HEPES)-buffered ACSF (the $\mathrm{NaHCO}_{3}$ was replaced by equimolar $\mathrm{HEPES} ; \mathrm{MgCl}_{2}$ was $0.5 \mathrm{~mm}$ ). The neuronal suspension was then transferred into a tissue culture dish (Lux, $35 \mathrm{~mm}$ diameter, NUNC). Before recordings, the neurons were thoroughly washed with a nominally $\mathrm{Mg}^{2+}$-free solution (see below). Experiments were performed between $15 \mathrm{~min}$ and $3 \mathrm{hr}$ following isolation of neurons.
Recordings of whole-cell NMDA responses. Patch electrodes were pulled from borosilicate thin-walled glass $(1.5 \mathrm{~mm}$ o.d., $1.12 \mathrm{~mm}$ i.d. with filament; Garner Glass Co.) on a Narishige PP-83 two-stage vertical puller. They were not fire polished or coated prior to use. Once filled electrodes had resistances of 4-7 M $\Omega$. Intracellular solutions contained (in mM) Cs-gluconate, 135; $\mathrm{CsCl}, 5 ; \mathrm{MgCl}_{2}, 2$; and $\mathrm{HEPES}$, 10, dissolved in HPLC-grade water (Water Omni Solv, EM Science). Using intracellular Cs-gluconate assured less noisy recordings than those obtained with CsCl. No exogenous $\mathrm{Ca}^{2+}$ buffers were added, since the $\mathrm{Ca}^{2+}$ contamination of the pipette solution was found to have negligible effects on the intracellular $\mathrm{Ca}^{2+}$ handling by acutely dissociated neurons (Köhr and Mody, 1991a). Whenever an ATP-regenerating system (Mg-ATP, $4 \mathrm{~mm}$; phosphocreatine, $25 \mathrm{~mm}$; creatine-phosphokinase, $50 \mathrm{U} / \mathrm{ml}$; all from Sigma; Forscher and Oxford, 1985; MacDonald et al., 1989) was added, the Cs-gluconate concentration was reduced to $110 \mathrm{~mm}$ and $\mathrm{MgCl}_{2}$ was omitted. The $\mathrm{pH}$ was adjusted to 7.25 with $\mathrm{CsOH}$ and final osmolarity ranged between 265 and 285 mOsm. To avoid a loss in efficacy of the ATP-regenerating system, the solutions were used freshly or were aliquoted into smaller batches and kept frozen at $-80^{\circ} \mathrm{C}$ until use. Solutions older then 1 week were discarded.

The $\mathrm{MgCl}_{2}$-free extracellular recording solution contained (in $\mathrm{mm}$ ) $\mathrm{NaCl}, 142 ; \mathrm{KCl}, 2.5 ; \mathrm{CaCl}_{2}, 2$ or 0.2 ; glucose, 10; HEPES, 10 ; glycine, 0.003 ; and tetrodotoxin (TTX; Calbiochem), 0.001 . The $\mathrm{pH}$ was adjusted to 7.25 with $\mathrm{NaOH}$; the osmolarity varied between 280 and 300 mOsm. NMDA stock solutions ( $50 \mathrm{~mm}$ ) were aliquoted into small batches and frozen at $-20^{\circ} \mathrm{C}$ until use. Final NMDA concentrations were oblained by dissolving stock solutions in the extracellular medium and applied by a modified solenoid-operated perfusion system (Spitzer and Bridge, 1989) consisting of two Teflon tubes (each $200 \mu \mathrm{m}$ i.d.) glued in parallel, or a square-lumen $(100 \times 100 \mu \mathrm{m})$ thin-septum $\Theta$-glass capillary. The two streams of the system were fed by gravity from independent reservoirs. The flow rate of $0.3 \mathrm{ml} / \mathrm{min}$ resulted in a flow velocity of $\approx 3 \mathrm{~cm} / \mathrm{sec}$ before reaching the neurons. During gigaseal ( $>3$ $G \Omega$ ) formation the neurons were perfused with control solution while the NMDA $(100 \mu \mathrm{M})$ flow from the second barrel was switched off. After recording a stable baseline in whole-cell voltage-clamp mode (Hamill et al., 1981), the flow of NMDA was turned on and produced a sharp boundary between the two streams of solutions. The NMDA-containing stream could be transiently moved onto the cell by triggering a solenoid (General Valve, Fairfield) for $4 \mathrm{sec}$ or $20 \mathrm{sec}$. Whole-cell NMDA currents were evoked at room temperature $\left(21-24^{\circ} \mathrm{C}\right)$ from a holding potential of $-57 \mathrm{mV}(-50 \mathrm{mV}$ plus $-7 \mathrm{mV}$ junction potential correction) and were amplified by a List EPC-7 (Adams and List Electronics) or an Axopatch-200 (Axon Instruments) amplifier. Voltage ramps (+50 to $-100 \mathrm{mV} ; 150 \mathrm{msec}$ duration, i.e., $1 \mathrm{mV} / \mathrm{msec}$ ) generated by a Tektronix RG 501 analog ramp generator were used to study the voltage dependence of the NMDA conductance. The ramp current in the absence of agonist was digitally subtracted from that in the presence of NMDA. All recordings were digitized at $44 \mathrm{kHz}$ and stored on videotapes following pulse-code modulation by a Neurocorder DR-484 (Neurodata Instruments Co.).

Cell-attached recordings of single NMDA channels. Borosilicate thickwalled glass (1.8 mm o.d., $1.15 \mathrm{~mm}$ i.d. without filament; Jencons, Ltd.) pulled in two stages on a Narishige PP-83 electrode puller was used for patch electrodes. Pipettes were coated with Sylgard resin (Dow Corning 184) and had resistances of 10-15 M . Cell-attached recordings were performed using an Axopatch 200 patch-clamp amplifier (Axon Instruments, Inc.) at $21-24^{\circ} \mathrm{C}$. The extracellular solution contained (in $\mathrm{mM}$ ) $\mathrm{Na}_{2} \mathrm{SO}_{4}, 140 ; \mathrm{Cs}_{2} \mathrm{SO}_{4}, 5 ; \mathrm{CaCl}_{2}, 1.8$; and HEPES, 10 (pH 7.25, 280295 mOsm). Stock solutions of NMDA (1 mM), glycine $(0.2 \mathrm{mM})$, and D-aminophosphonovaleric acid $(0.5 \mathrm{~mm})$ were frozen at $-20^{\circ} \mathrm{C}$ until use.

Steady-state cell-attached recordings of NMDA channel activity were obtained by using 1,5 , or $10 \mu \mathrm{M} \mathrm{NMDA}$ and $3 \mu \mathrm{M}$ glycine in the recording pipettes. The agonist was dissolved in the extracellular solution (McLarnon and Curry, 1990) and was filled into the recording electrodes. The use of low agonist concentrations may have prevented pronounced desensitization of NMDA channels. Given the low probability of NMDA channel openings, the number of active NMDA channels per patch remained unknown, even in the absence of simultaneous double openings, as we did not perform an elaborate stochastic analysis (Colquhoun and Hawkes, 1990).

Data analysis. Whole-cell NMDA responses were analyzed off line using the SCAN and SPAN programs of the Strathclyde Electrophysiology Software (courtesy of J. Dempster, University of Strathclyde, UK). 
Membrane currents were high-pass filtered at $0.1 \mathrm{~Hz}$ and low-pass filtered at $1 \mathrm{kHz}$ (8-pole Butterworth, $-3 \mathrm{~dB}$; Frequency Devices, model 9002) and digitized at $2 \mathrm{kHz}$ in blocks of 256 points. Data blocks containing artifacts were removed. For each cell, the whole duration of the NMDA-induced current was recorded but only the steady-state portion was analyzed. Baseline current was recorded before and after each NMDA application. The baseline noise spectrum was subtracted from the spectrum in the presence of NMDA. Using a LevenbergMarquardt algorithm, the power spectra were fitted with one or the sum of two Lorentzian functions of the form

$$
L(f)=\frac{S_{0}(1)}{1+\left(f / \int_{\text {slow }}\right)^{2}}+\frac{S_{0}(2)}{1+\left(f / \int_{\text {fast }}\right)^{2}},
$$

where $L(f)$ is the spectral density at frequency $f, S_{0}(1)$ and $S_{0}(2)$ are the low-frequency asymptotes, and $f_{\text {slow }}$ and $f_{\text {fast }}$ are the respective cutoff frequencies $\left(f_{c}\right)$ at which the spectral power of each component is half. The characteristic mean lifetime of NMDA channel was calculated from each component using the formula

$$
\tau=1 /\left(2 \pi f_{c}\right) \text {. }
$$

The single-channel current was estimated from the relationship between mean DC current and variance of the high-pass-filtered current. The single-channel conductance calculated in this manner was comparable to the value obtained from the power spectrum assuming the reversal potential of NMDA currents to be $0 \mathrm{mV}$ (compare Fig. 5).

The ramp currents in the presence of NMDA and after subtraction of ramps in the absence of agonist were used to quantify the voltage dependence of the $\mathrm{Mg}^{2+}$ block according to the Woodhull (1973) model (cf. Ascher and Nowak, 1988; Jahr and Stevens, 1990a,b; Chen and Huang, 1992; but see Hille and Schwarz, 1978; Johnson and Ascher, 1990):

$$
\frac{g}{g_{\mathrm{MAx}}}-1-\frac{\left[\mathrm{Mg}^{2+}\right]_{o}}{K_{\mathrm{Mg} 0} \exp \left(z^{\prime} F V / R T\right)+\left[\mathrm{Mg}^{2+}\right]_{o}}
$$

where $\left[\mathrm{Mg}^{2+}\right]_{o}$ is the extracellular $\mathrm{Mg}^{2+}$ concentration, $K_{\mathrm{Mg} 0}$ is the apparent dissociation constant of $\mathrm{Mg}^{2+}$ at $0 \mathrm{mV}, z^{\prime}=z \cdot \delta$ (Hille and Schwarz, $1978 ; \delta$ is the relative distance within the membrane where the block takes place), and $z, F, R$, and $T$ have their usual meaning.

For the analysis of single channels, recordings were filtered through the $10 \mathrm{kHz}$ Bessel filter (4-pole, $-3 \mathrm{~dB}$ ) of the amplifier and were stored in a pulse-code-modulated digitized form $(44 \mathrm{kHz}$; Neurodata) on videotapes. Then, data were analyzed off line with the PAT program of the Strathclyde Electrophysiology Software (courtesy of J. Dempster), using a $50 \%$ threshold crossing algorithm for event detection. For analysis the continuous records were filtered at $2 \mathrm{kHz}$ (8-pole Bessel, $-3 \mathrm{~dB}$; Frequency Devices model $902 \mathrm{LPF}$ ) and continuously sampled at 20 kHz (DT 2821 A/D board, Data Translation using an Intel 80486-based computer). The analysis of dwell-time distributions was done using software written and developed by Y.D. and I.M. Shut time distributions were calculated by fitting several exponential distributions with a Simplex-based maximum likelihood method to log-binned intervals at 9 or $10 \mathrm{bins} /$ decade plotted on a square-root ordinate (Sigworth and Sine, 1987; Gibb and Colquhoun, 1991, 1992). Critical closed times $\left(T_{c}\right)$ for determination of burst, cluster, and supercluster durations were calculated from the respective time constants of the shut time distributions according to Gibb and Colquhoun (1992) by solving the following equation for $T_{c}$ (Colquhoun and Sakmann, 1985):

$$
1-\exp \left(-T_{c} / \tau_{i}\right)=\exp \left(-T_{c} / \tau_{i+1}\right)
$$

where $\tau_{i}$ is the $i$ th time constant from the distribution of shut times, and $i=2,3$, or 4 .

The open probability was calculated as the ratio between total open time and total recording time (2-6 min) during stable NMDA channel activity at $-70 \mathrm{mV}$. The $p_{\text {open }}$ during bursts, clusters, and superclusters was calculated by dividing the total open time during these groups of openings and the total duration of the events. As single openings, if separated by gaps longer than $T_{c}$, are counted as bursts, clusters, and superclusters, this method will overestimate the $p_{\text {open }}$ during actual multiple openings.

Statistical analyses. To distinguish between the sum of several normal distributions in a set of data points, cumulative probabilities of the variable $x($ i.e., $P(x)$ ) were calculated and fitted by one or more normal curves approximated by the logistic equation (Barlow 1990)

$$
P(x)=\sum_{i=1}^{n} R_{i} \frac{x^{p_{i}}}{x^{p_{i}}+\bar{x}_{i}^{p_{i}}}
$$

where $R_{1}, \ldots, R_{i}$ are the ratios of the $n$ normal distributions (such as $\left.\Sigma_{i=1}^{n} R_{i}=1\right), \bar{x}_{1}, \ldots, \bar{x}_{n}$ are the means, and $p_{1}, \ldots, p_{n}$ are steepness factors related to the $n$ standard deviations $\left(\mathrm{SD}_{1}, \ldots, \mathrm{SD}_{n}\right)$ through

$$
\mathrm{SD}_{i}=\bar{s}_{i}\left\{1-[0.1586 /(1-0.1586)]^{1 / p_{i}}\right\} .
$$

The curves were generated by the Simplex-based fitting method (Caceci and Cacheris, 1984) in which all parameters were allowed to vary independently until the least sum of residuals squared was established.

The Kolmogorov-Smirnov (KS) test was used to compare two cumulative probability distributions to each other or to compare a probability distribution to a theoretical curve. These distributions can be readily used for statistical tests without any assumptions about the nature of the underlying theoretical probability distributions (e.g., Press et al., 1988). Other statistical analyses included one-way ANOVA and the nonparametric Mann-Whitney $U$ test. All results are expressed as mean \pm standard error of the mean (SEM) unless otherwise indicated. Significance level was set at 0.05 (two-tailed tests).

\section{Results}

Whole-cell NMDA currents of acutely isolated control granule cells and the effect of extracellular calcium

The characteristics of whole-cell NMDA currents have been extensively investigated in cultured embryonic neurons (Ascher et al., 1988; Cull-Candy et al., 1988; Mayer et al., 1988; CullCandy and Usowicz, 1989a), but only a limited number of studies have examined whole-cell NMDA responses in acutely isolated mature neurons (e.g., Smith et al., 1991). In order to ascertain the identity of whole-cell NMDA responses in neurons isolated from control adult and chronically altered tissue, as is the case in our preparation, some known properties of NMDA channels had to be tested in our preparation.

In physiological concentrations of extracellular $\mathrm{Na}^{+}(142 \mathrm{~mm})$ and $\mathrm{Ca}^{2+}$ (2 $\left.\mathrm{mM}\right)$, rapid application of 50-200 $\mu \mathrm{M}$ NMDA in nominally $\mathrm{Mg}^{2+}$-free solutions evoked dose-dependent inward currents at negative membrane potentials and outward currents at positive membrane potentials. Extracellular glycine (Johnson and Ascher, 1987) potentiated the NMDA currents (not shown). Reducing the $\left[\mathrm{Ca}^{2+}\right]$, to $0.2 \mathrm{~mm}$ caused an increase in the size of whole-cell NMDA currents. Desensitization was also dependent on the extracellular $\mathrm{Ca}^{2+}$ concentration (Clark et al., 1990; Legendre et al., 1993). Peak NMDA currents decayed by $54.4 \%$ $(n=11)$ in $2.0 \mathrm{~mm}\left[\mathrm{Ca}^{2+}\right]_{0}$ and by $30.6 \%(n=8)$ in $0.2 \mathrm{~mm}$ $\left[\mathrm{Ca}^{2+}\right]_{o^{*}}$. No secondary increase of NMDA currents was noted in the absence of intracellular $\mathrm{Ca}^{2+}$ chelators (cf. Markram and Segal, 1992). This is contrary to observations in cultured hippocampal neurons (Clark et al., 1990) and may be due to the fact that in acutely isolated granule cells $\left[\mathrm{Ca}^{2+}\right]_{i}$ is sufficiently buffered to provide a large driving force for $\mathrm{Ca}^{2+}$ entry even in the absence of an added intracellular $\mathrm{Ca}^{2+}$ chelator (Köhr and Mody, 1991a).

Estimates for the mean channel lifetime and single-channel conductance were derived from spectral analysis of the steadystate portion of whole-cell NMDA currents. The net NMDA power spectra in 2.0 and $0.2 \mathrm{~mm}\left[\mathrm{Ca}^{2+}\right]_{\omega}$ could be best fit by double Lorentzian functions. The power of the spectral density increased significantly upon reducing $\left[\mathrm{Ca}^{2+}\right]_{o}$ to $0.2 \mathrm{mM}$. At the same time, the corner frequencies decreased: $\tau_{\text {slow }}$ varied between 3.4 and $5.8 \mathrm{msec}$ in $2.0 \mathrm{~mm}\left[\mathrm{Ca}^{2+}\right]_{o}(n=11)$ and between 4.2 and $6.2 \mathrm{msec}$ in $0.2 \mathrm{mM}\left[\mathrm{Ca}^{2+}\right]_{o}(n=8)$ while $\tau_{\text {fast }}$ ranged between 0.8 and $1.8 \mathrm{msec}$ in $2.0 \mathrm{~mm}\left[\mathrm{Ca}^{2+}\right]_{o}$ and between 0.6 and 2.3 
msec in $0.2 \mathrm{~mm}\left[\mathrm{Ca}^{2+}\right]_{\circ}$. Only $\tau_{\text {slow }}$ was significantly increased by lowering extracellular $\mathrm{Ca}^{2+}$ (Mann-Whitney $U$ test, $\left.p<0.01\right)$.

Consistent with an increase in peak NMDA current, the single-channel current increased from $1.8 \mathrm{pA}$ to $2.6 \mathrm{pA}$ after lowering $\left[\mathrm{Ca}^{2+}\right]_{0}$ from 2.0 to $0.2 \mathrm{mM}$. Single-channel conductance ranged between 21 and $35 \mathrm{pS}$ in $2.0 \mathrm{~mm}\left[\mathrm{Ca}^{2+}\right]_{o}(n=11)$ and between 40 and $53 \mathrm{pS}$ in $0.2 \mathrm{~mm}\left[\mathrm{Ca}^{2+}\right]_{0}(n=8)$. The significant (Mann-Whitney $U$ test, $p<0.001$ ) increase of the NMDA channel conductance in $0.2 \mathrm{mM} \mathrm{Ca}^{2+}$ probably reflects the relief of the blocking action by $\mathrm{Ca}^{2+}$ allowing more $\mathrm{Na}^{+}$influx during NMDA application (Mayer and Westbrook, 1987; Gibb and Colquhoun, 1992).

\section{Increased requirement of kindled NMDA receptors for} intracellular high-energy phosphates

The intracellular high-energy phosphate support system (ATP, phosphocreatine, and crcatinc phosphokinasc) prevents the rundown of whole-cell NMDA currents in cultured hippocampal neurons independent of the extent of intracellular $\mathrm{Ca}^{2+}$ buffering (MacDonald et al., 1989). If kindling alters the phosphorylation state of NMDA channels, NMDA currents should run down differently in acutely isolated control versus kindled neurons. To test this hypothesis, currents evoked by $100 \mu \mathrm{M}$ NMDA were studied in normal $\left[\mathrm{Ca}^{2+}\right]_{o}(2.0 \mathrm{mM})$ when the ATP regeneration solution was either included (for simplicity, further referred to as ATP) or omitted from the recording pipette (further referred to as absence of ATP). During the entire recording period (up to $90 \mathrm{~min}$ ) in either control or kindled neurons, the peak NMDA current and its desensitization remained constant regardless of the presence or absence of ATP. At $4 \mathrm{sec}$ following NMDA applications the currents decayed by $51.7 \pm 1.6 \%(n=23)$ in control neurons and by $50.5 \pm 2.2 \%(n=24)$ in kindled neurons. Figure 1 shows raw recordings of whole-cell NMDA currents in two different control and three different kindled neurons.

In control neurons, the peaks of NMDA currents were not significantly enhanced in the presence of ATP (see Table 1, Fig. $3 A$ ). In kindled neurons, the amplitudes of NMDA currents showed great variability but were significantly reduced in the absence of ATP (ANOVA, $p<0.05$ ). The highly variable current amplitudes after kindling may be a consequence of multiple NMDA channel populations. Therefore, the measurements of NMDA current amplitudes in the presence or absence of ATP were pooled and plotted as a cumulative probability distribution to distinguish between possible multiple normal distributions (e.g., Fig. 3B). The data were fitted with one and two sigmoidal curves representing one or two normal distributions (see Materials and Methods). All peak NMDA currents recorded in control neurons showed one normal distribution with a mean of $80.5 \pm 15.6 \mathrm{pA}( \pm \mathrm{SD})$. The distribution of amplitudes in kindled neurons, fitted with one normal distribution, had a mean of $47.4 \pm 29.1 \mathrm{pA}( \pm \mathrm{SD})(\mathrm{KS}, p=0.011)$. The fit was not significantly improved by a bimodal cumulative function.

\section{Power spectra of NMDA-induced noise in control and kindled neurons}

The properties of NMDA channel ensembles after kindling were investigated by fluctuation analysis of whole-cell NMDA current noise. Figure 2 illustrates whole-cell NMDA power spectra in a control and a kindled neuron. Only the steady-state portion of the noise (last $15 \mathrm{sec}$ of the $20 \mathrm{sec}$ response) was used for the analysis. In each case the net power spectrum was fitted by double Lorentzian functions with two distinct corner frequen-

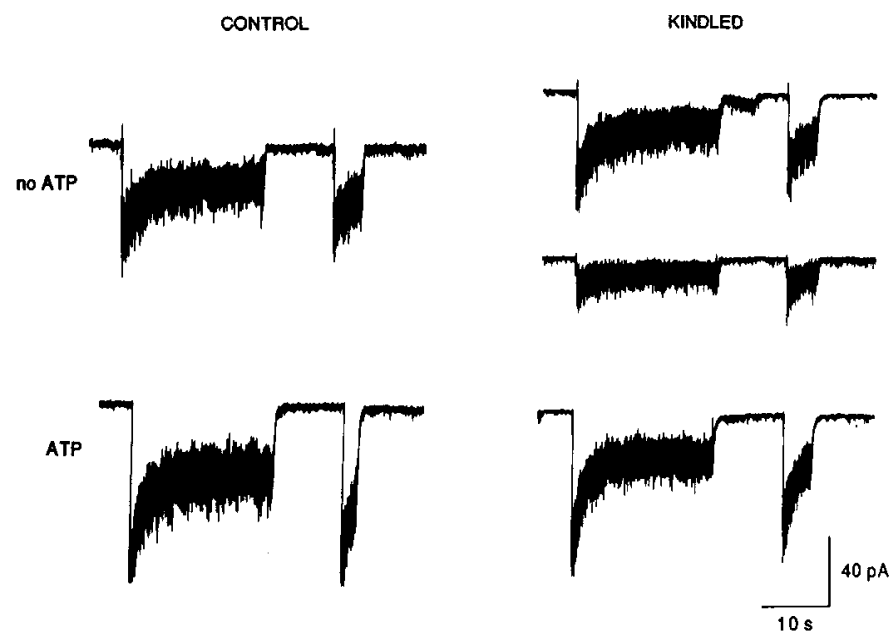

Figure 1. Raw traces of NMDA-induced whole-cell responses of two control and three kindled neurons obtained in $2.0 \mathrm{mM}\left[\mathrm{Ca}^{2+}\right]_{o}$ in the presence or absence of an intracellular ATP regeneration system. In the presence of ATP peak NMDA currents were not significantly enhanced in control neurons. After kindling, the NMDA responses showed a large variability, with consistently smaller amplitudes (ANOVA, $p<0.05$ ) in the absence of ATP (see also Table 1). In both control and kindled neurons the peak NMDA currents decayed on average by $50 \%$. $V_{n}$ was $-57 \mathrm{mV}$; duration of NMDA $(100 \mu \mathrm{M})$ application was $20 \mathrm{sec}$ and 4 sec.

cies. The corresponding mean channel lifetimes ( $\tau_{\text {slow }}$ and $\left.\tau_{\text {fast }}\right)$ are indicated for the control and kindled neuron in Figure 2. The average $\tau_{\text {fast }}$ was not significantly different between control and kindled cells. The values ranged between 0.8 and $1.8 \mathrm{msec}$ in control cells and between 0.7 and $2.4 \mathrm{msec}$ in kindled cells (sce Table 1). Detailed analysis of the $\tau_{\text {slow }}$ is shown in Figure 3, $C$ and $D$. The presence of ATP had no significant effect on $\tau_{\text {slow }}$ of either control or kindled neurons. In control cells $\tau_{\text {slow }}$ varied between 3.4 and $6.3 \mathrm{msec}$ ( $n=17$; coefficient of variation, $\mathrm{CV},=20.4 \%)$. In kindled neurons both mean and variance increased. In kindled cells, $\tau_{\text {slow }}$ ranged between 3.6 and $8.3 \mathrm{msec}$ ( $n=17 ; \mathrm{CV}=25.1 \%$ ) (and was significantly different in the presence of ATP from the values oblained in control cells; see Table 1). After plotting all values of $\tau_{\text {slow }}$ as a cumulative probability function, $\tau_{\text {slow }}$ showed one normal distribution in control neurons (mean, $4.3 \mathrm{msec}$ ) but two normal distributions in kindled neurons (Fig. $3 D$; KS, $p=0.005$ for two normal distributions). One population with an average mean open time of $4.6 \mathrm{msec}$ is comparable to all control neurons. The second average mean open time of $7.1 \mathrm{msec}$ could only be found in kindled neurons and had no counterpart in control neurons.

The single-channel current calculated from the mean current versus variance plots was comparable in control and kindled cells, and did not correlate with the presence or absence of ATP (see Table 1).

\section{Correlation between mean lifetime and peak NMDA current}

The cumulative probability plot of all NMDA channel mean lifetimes (Fig. $3 D$ ) yielded two normal distributions for kindled neurons. The lifetimes that could be separated into two populations will be referred to below for sake of simplicity as $4.5 \mathrm{msec}$ and $7.0 \mathrm{msec}$ groups. Thus, control neurons consisted of only one group, that is, the $4.5 \mathrm{msec}$ group. For each group the corresponding peak NMDA currents were plotted as mean values in Figure 4 in the absence and presence of ATP. When 
CONTROL

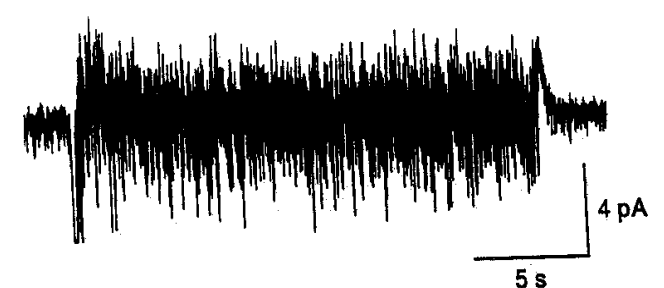

Figure 2. Fluctuation analysis of NMDA responses in a control and a kindled neuron in the presence of intracellular ATP $\left(V_{h}=-57 \mathrm{mV}\right)$. Top, The high-pass-filtered chart record shows the increase in current noise during a $20 \mathrm{sec}$ NMDA application in both control and kindled neuron. Middle, Spectral density of the current noise of the last $15 \mathrm{sec}$ (mean current of the steady-state level, 69.1 pA and $50.9 \mathrm{pA}$ in the control and kindled neuron, respectively). Net spectra ( $\bullet$, control; $\Delta$, kindled) were each fitted by the sum of two Lorentzian components (continuous line). Background noise spectra (indicated by $O$, control, and $\triangle$, kindled) were subtracted. The cutoff frequencies (indicated by arrows) of the two components (dashed lines) are $35.8 \mathrm{~Hz}$ and $95.6 \mathrm{~Hz}$ (control) and $21.9 \mathrm{~Hz}$ and 141 $\mathrm{Hz}$ (kindled); these correspond to the indicated time constants ( $\tau_{\text {slow }}$ and $\left.\tau_{\text {fast }}\right)$. Bottom, The single-channel current estimated from the plot of mean current versus variance in the control neuron was $1.65 \mathrm{pA}$, consistent with a singlechannel conductance of $28.9 \mathrm{pS}$. The single-channel current in the kindled neuron was $1.60 \mathrm{pA}$, yielding a singlechannel conductance of $28.1 \mathrm{pS}$.
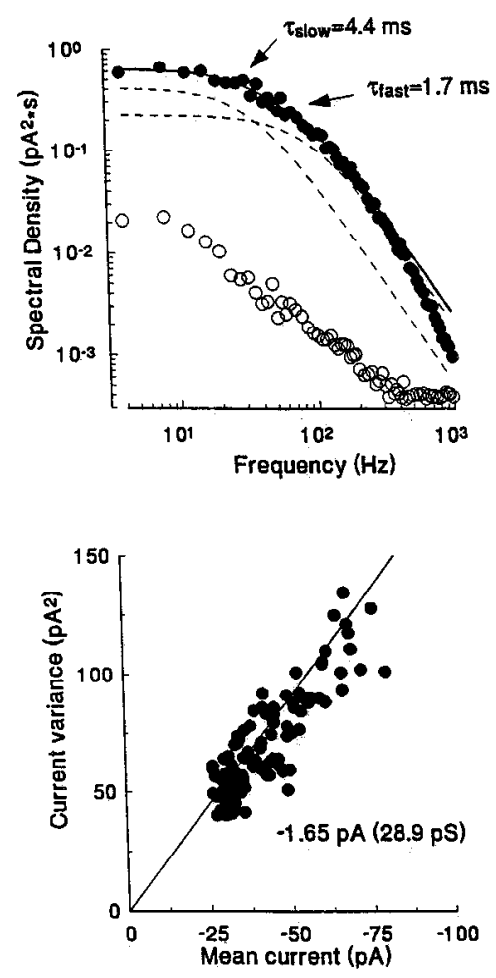

KINDLED
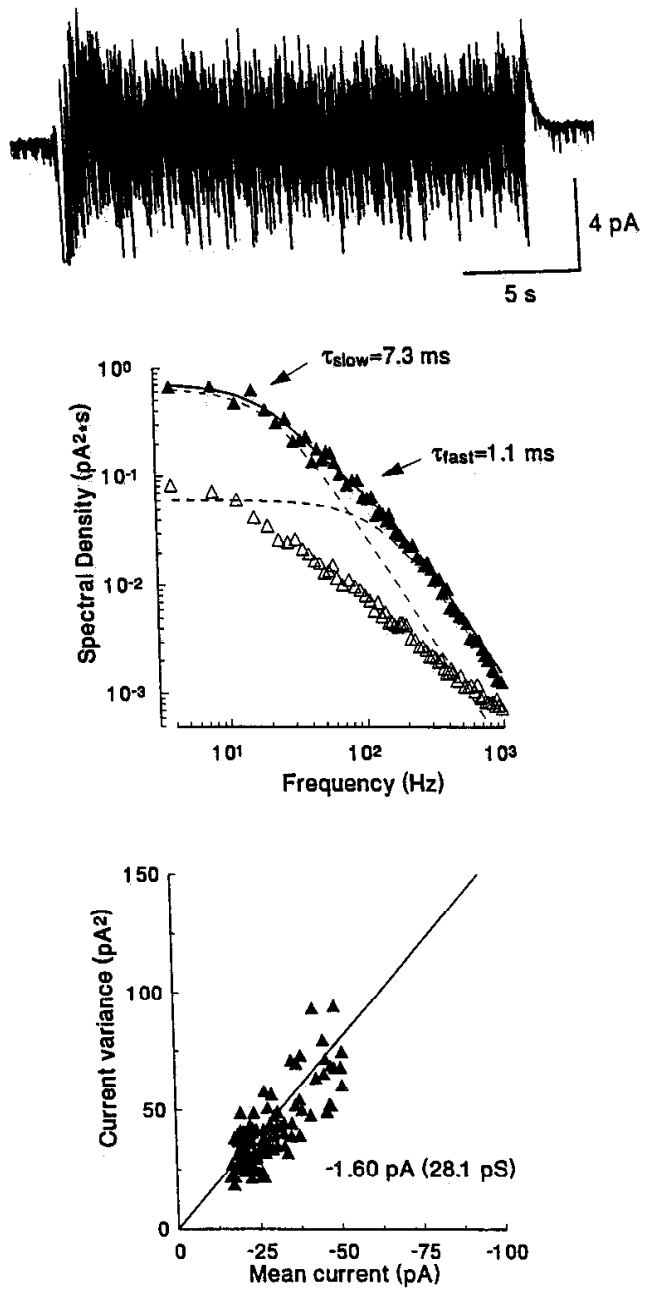

displayed in this manner, the data clearly show two major differences between control $(n=17)$ and kindled $(n=17)$ neurons. First, NMDA channels with open times of 7.0 msec are only present after kindling $(n=8)$. An effect of intracellular ATP on this channel is unlikely, as peak NMDA currents in this group were unaffected by the presence of ATP. Second, NMDA channels with open times around $4.5 \mathrm{msec}$ are present in both control $(n=17)$ and kindled $(n=9)$ neurons, but the sensitivity of these channels to intracellular ATP appears to be changed after kin- dling. In the absence of ATP, the amplitudes of NMDA currents through the $4.5 \mathrm{msec}$ channels were significantly diminished (ANOVA, $p<0.002$ ) in kindled neurons but not in controls.

\section{Voltage-dependent block of NMDA channels by $\mathrm{Mg}^{2+}$ after kindling}

NMDA channels are blocked in a voltage-dependent manner by $\mathrm{Mg}^{2+}$ (Mayer and Westbrook, 1987; Asher and Nowak, 1988) and this block may be the site of plastic alterations during brain

Table 1. Whole-cell NMDA current and NMDA channel parameters derived from noise spectra evoked by $100 \mu_{M}$ NMDA in the absence $(-)$ or presence $(+)$ of an ATP regeneration system

\begin{tabular}{llllllll} 
Group & $n$ & ATP & $\begin{array}{l}\text { Peak } \\
(\mathrm{pA})\end{array}$ & $\begin{array}{l}\text { Desensi- } \\
\text { tization } \\
(\%)\end{array}$ & $\begin{array}{l}\tau_{\text {slow }} \\
(\mathrm{msec})\end{array}$ & $\begin{array}{l}\tau_{\text {fast }} \\
(\mathrm{msec})\end{array}$ & $\begin{array}{l}\gamma \\
(\mathrm{pS})\end{array}$ \\
\hline Control & 11 & - & $81.9 \pm 5.7$ & $54.4 \pm 2.4$ & $4.5 \pm 0.3$ & $1.3 \pm 0.1$ & $28.4 \pm 1.3$ \\
Kindled & 8 & - & $49.4 \pm 15.9^{*}$ & $49.4 \pm 4.7$ & $5.5 \pm 0.6$ & $1.6 \pm 0.2$ & $27.1 \pm 2.2$ \\
Control & 6 & + & $109.1 \pm 10.2$ & $54.5 \pm 2.6$ & $4.7 \pm 0.4$ & $1.4 \pm 0.1$ & $31.2 \pm 1.5$ \\
Kindled & 9 & + & $93.9 \pm 20.2$ & $52.5 \pm 3.6$ & $6.2 \pm 0.4^{*}$ & $1.4 \pm 0.1$ & $28.9 \pm 1.5$
\end{tabular}

The amount of desensitization (expressed as percentage) was estimated as the ratio between peak and steady-state NMDA current. Lorentzian functions fitted to two-component power spectra yielded $\tau_{\text {slow }}$ and $\tau_{\text {fasi }}$, the estimates of the slow and fast mean channel lifetimes. The single-channel conductance $(\gamma)$ was calculated from the slope of the linear regression fitted to the relationship between mean current and current variance, assuming a reversal potential of $0 \mathrm{mV}$. Values are given as mean \pm SEM. Holding potential was $-57 \mathrm{mV}$. Significant differences (Mann-Whitney $U$ test, $p<0.01$ ) between control and kindled neurons are indicated by asterisks. 
A

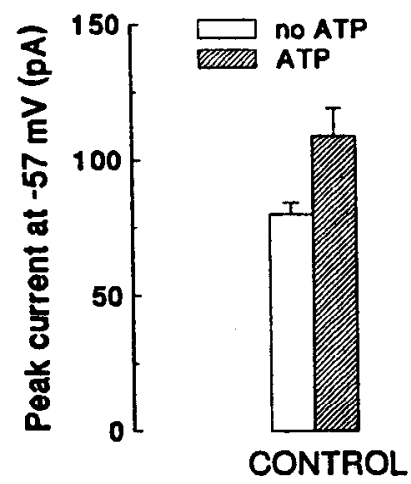

B

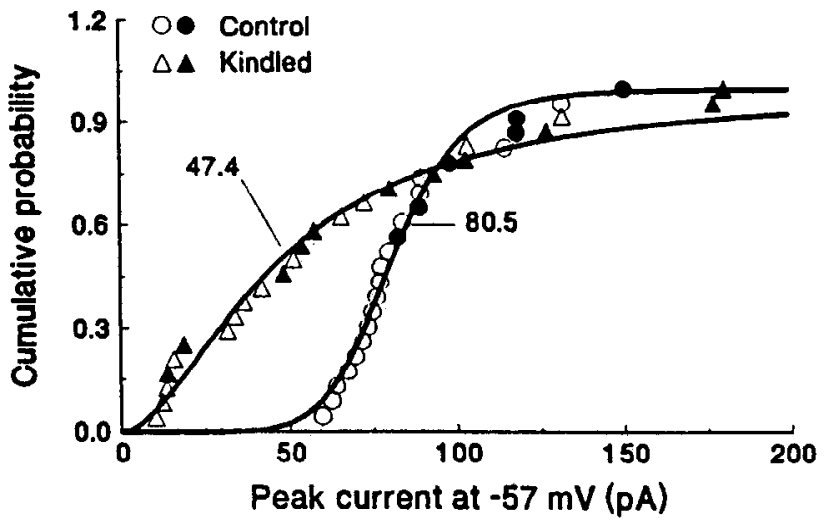

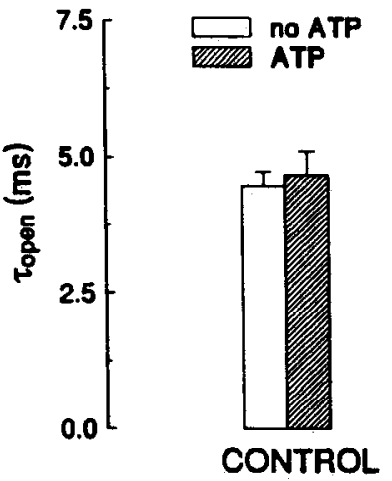

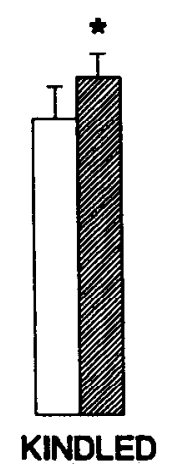

D

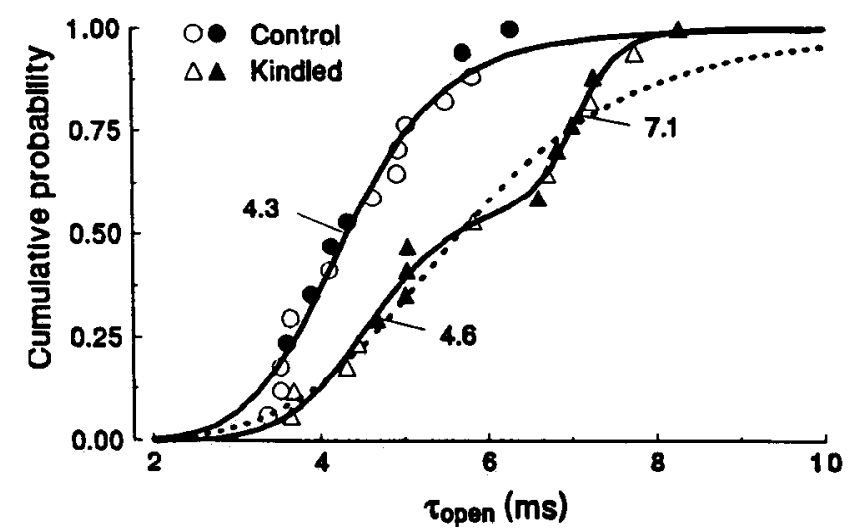

Figure 3. A, Mean values ( \pm SEM) of peak NMDA currents in 23 control and 24 kindled neurons in the absence or presence of ATP. Peak NMDA currents recorded in the absence of ATP in kindled neurons were smaller than those in any of the other three groups $[\mathrm{ANOVA} F(3,43)=4.65$, $p=0.013]$. Note the increase in variability of the NMDA currents after kindling indicated by the size of the error bars. $B$, The data in $A$ were pooled for the control $(\bullet, 0)$ and kindled $(\Delta, \Delta)$ neurons regardless of the presence (solid symbols) or absence of ATP (open symbols). When plotted as cumulative probability distributions to resolve possible bimodalities, single normal distributions with means $( \pm \mathrm{SD})$ of $80.5 \pm 15.6 \mathrm{pA}$ and 47.4 $\pm 29.1 \mathrm{pA}$ were found to fit best in control and kindled neurons, respectively. The sum of two normal distributions (not shown) produced no significantly better fits than single normal distributions. $C$, Mean values $\left( \pm\right.$ SEM) of slow mean open times $\left(\tau_{\text {open }}\right)$ of the NMDA channels in 17 control and 17 kindled neurons as measured by fluctuation analysis in the absence or presence of the intracellular ATP regeneration system. After kindling both mean and variance increased regardless of the presence or absence of ATP. D, The pooled control $(\boldsymbol{\theta}, O)$ and kindled $(\Delta, \Delta)$ data are plotted as cumulative probability distributions (open symbols, intracellular ATP support system absent; solid symbols, intracellular ATP support system present). The data points obtained in control neurons are best approximated by a single normal distribution (4.3 $\pm 0.9 ;$ mean \pm SD). After kindling, two normal distributions (solid line) with significantly different means ( $4.6 \pm 0.8$ and $7.1 \pm 0.4 \mathrm{msec})$ fit the data better (KS, $p=0.005$ ) than a single distribution (dotted line; $\mathrm{KS}, p=0.392$ ).

development (Ben-Ari et al., 1989; Morrisett et al., 1990; Brady et al., 1991). In order to investigate the voltage dependence of NMDA-induced conductances in the presence of physiological $\left[\mathrm{Mg}^{2+}\right]_{o}(1 \mathrm{mM})$ or in the nominal absence of $\left[\mathrm{Mg}^{2+}\right]_{o}$ (no added $\mathrm{Mg}^{2+}$ ), control or kindled neurons were depolarized to $+50 \mathrm{mV}$ for $10 \mathrm{sec}$ to fully inactivate most voltage-dependent conductances and were subsequently hyperpolarized to $-100 \mathrm{mV}$ by an analog voltage ramp $(150 \mathrm{msec})$. To obtain the $I / V$ relationship of NMDA conductances, an average agonist-free ramp current elicited before and after NMDA application was subtracted from that recorded in the presence of the agonist (Fig. 5). In the presence of $\mathrm{Mg}^{2+}$ the $I / V$ relationships illustrate the characteristic nonlinear voltage dependence with a region of negative slope conductance in both control and kindled neurons. However, modeling the voltage-dependent block by $\mathrm{Mg}^{2+}$ showed pronounced differences between control and kindled neurons. The apparent dissociation constant for $\mathrm{Mg}^{2+}$ at $0 \mathrm{mV}$ was in the range of $1.55-1.87 \mathrm{~mm}$ in control neurons ( $n=4$; cf. Jahr and Stevens, 1990a,b; Chen and Huang, 1992; but see the value of $8.8 \mathrm{~mm}$ of Asher and Nowak, 1988) whereas NMDA channels in kindled neurons showed a significantly lower affinity for $\mathrm{Mg}^{2+}$ at $0 \mathrm{mV}$ (range of $K_{\mathrm{Mg} 0}, 10.1-13.9 \mathrm{~mm} ; n=3$ ). The site of the $\mathrm{Mg}^{2+}$ block was $81 \%$ of the way through the membrane field (range of $\delta, 0.78-0.83, n=4$; cf. Jahr and Stevens, 1990a; Chen and Huang, 1992) in control neurons assuming that the channels conform to a simple Woodhull (1973) model. In kindled granule cells, however, the fit to the $I / V$ curves similar to that illustrated in Figure $5 A$ could only be accomplished by increasing $\delta$ to values between 1.58 and 1.68. A value of $\delta>1.0$ makes sense only for a more complex multi-ion pore channel model (Hille and Schwarz, 1978; Johnson and Ascher, 1990). This finding indicates that the nature of the $\mathrm{Mg}^{2+}$ block must have been altered after kindling, as a simple model could no longer accurately describe the $\mathrm{Mg}^{2+}$-dependent block in kindled neurons 

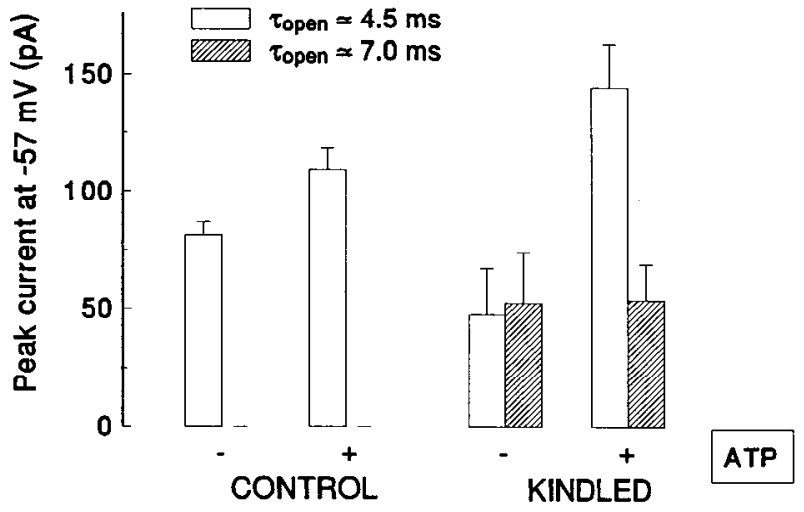

Figure 4. Correlation between mean open time of the NMDA channel and peak NMDA current in the absence (-) and presence (+) of ATP. All data shown in Figure 6 are included. The peak NMDA currents recorded in control neurons were assigned to one group of NMDA channels with a mean lifetime close to $4.5 \mathrm{msec}(n=17)$. Peak NMDA currents in kindled neurons were included in the group with a mean lifetime close to $4.5 \mathrm{msec}(n=9)$ or in the group with a mean lifetime of about $7 \mathrm{msec}(n=8)$ based on the separation of the binormally distributed data (Fig. $3 D$ ). Two clear differences between NMDA channels of control and kindled neurons emerge. After kindling, a novel group of NMDA channels with a mean lifetime of about 7 msec emerged. NMDA channels with a mean lifetime of about $4.5 \mathrm{msec}$ were present in both control and in kindled neurons, but after kindling, this channel became more sensitive to intracellular high-energy phosphates [ANOVA: $F(3,22)-7.96, p-0.002]$.

(see also Johnson and Ascher, 1990). Close to the resting potential of granule cells $(-80 \mathrm{mV})$, the calculated affinity of the $\mathrm{Mg}^{2+}$ block is higher in kindled neurons $(0.4-1.2 \mu \mathrm{M})$ than in controls $(7.8-11.5 \mu \mathrm{M})$, but the conductance increases much steeper upon depolarization (see inset in Fig. $5 A$ ), with a 12-15 $\mathrm{mV}(n=3)$ negative shift in the value of the membrane voltage at which half-activation of NMDA conductance occurs (Fig. $5 \mathrm{~A}$, inset).

In nominally $\mathrm{Mg}^{2+}$-free solutions, the $I / V$ relationships were linear between +50 and $-60 \mathrm{mV}$ (Fig. $5 B$ ). A slight voltage sensitivity of the NMDA conductance below $-60 \mathrm{mV}$ was still present in both control $(n=5)$ and kindled $(n=3)$ neurons and may have resulted from a residual $\mathrm{Mg}^{2+}$ contamination of the extracellular solution or from $\left[\mathrm{Ca}^{2+}\right]_{o}$ exerting a $\mathrm{Mg}^{2+}-$ like effect (Mayer et al., 1988). On average, recordings from control and kindled neurons showed comparable linear $I / V$ relationships for whole-cell ramp NMDA currents in the nominal absence of $\mathrm{Mg}^{2+}$.

\section{Single-channel conductance}

Single-channel currents produced by 1,5 and $10 \mu \mathrm{M}$ NMDA were examined in cell-attached patches of acutely isolated control $(n=29)$ and kindled $(n=35)$ dentate gyrus granule cells. Because of improved resolution at potentials away from reversal, all patches were first held with $0 \mathrm{mV}$ holding potential close to the resting membrane potential of -65 to $-70 \mathrm{mV}$. Using NMDA as an agonist, patches were dominated by openings to only one main amplitude level and the occasional subconductance state openings were excluded from the analysis. Examples of single-channel currents at different patch potentials in a control and a kindled cell are shown in Figure 6. As the currentvoltage relationships indicate, the amplitudes of single-channel currents were linearly dependent on holding potentials between +50 and $-120 \mathrm{mV}$. Each data point represents the mean and
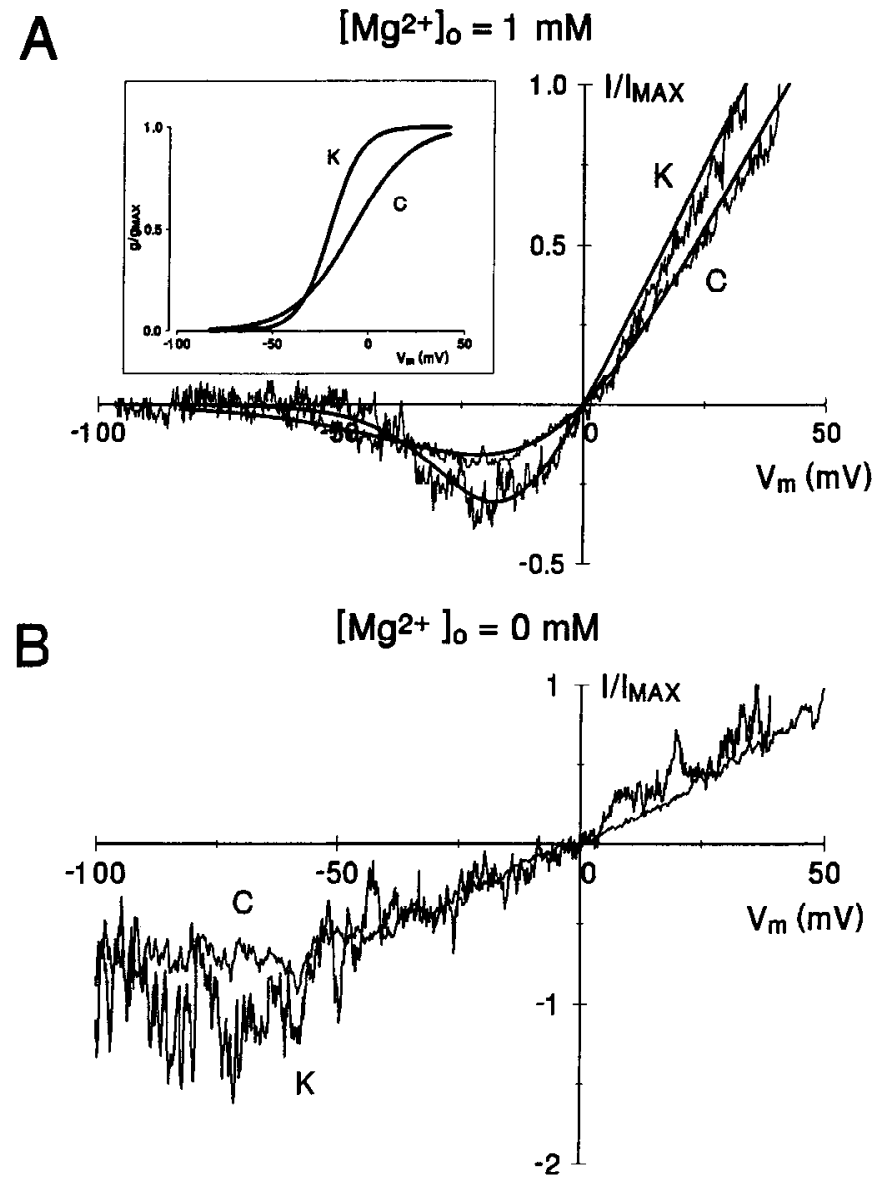

Figure 5. Continuous current-voltage relationships of NMDA conductances revealed clear differences in the voltage-dependent $\mathrm{Mg}^{2+}$ block between control $(C)$ and kindled $(K)$ neurons. $A$, In $1 \mathrm{mM}\left[\mathrm{Mg}^{2+}\right]_{0}$ the nonlinear voltage dependence of the NMDA conductance was signifcantly altered in a kindled neuron. The solid lines indicate the fits to the equation described in Materials and Methods. The fitted constants were as follows: control, $z^{\prime}=z \cdot \delta=1.68, K_{\mathrm{Mg} 0}=1.74 \mathrm{~mm}$; kindled, $z^{\prime}$ $=z \cdot \delta=3.19, K_{\mathrm{Mg} 0}=12.39 \mathrm{mM}$. The inset shows the voltage dependence of the relative NMDA conductances. Note the markedly steeper voltage dependence in the kindled neuron. The half-activation voltages were $-8.2 \mathrm{mV}$ and $-20.2 \mathrm{mV}$ in the control and kindled neuron, respectively. $B$, In two different cells and in the nominal absence of $\left[\mathrm{Mg}^{2+}\right]_{o}$, the NMDA conductance varies linearly with the membrane voltage in both control and kindled neuron. There was, however, a small residual voltage-dependent block at membrane potentials more hyperpolarized than $-60 \mathrm{mV}$ (see Results for details).

the SD of a Gaussian distribution fit to the amplitude histogram constructed at various patch potentials. In both control and kindled cells the reversal potential of the NMDA-induced currents was near $0 \mathrm{mV}$ considering the comparable resting membrane potential of acutely isolated control and kindled granule cells (range, -60 to $-65 \mathrm{mV}$; Köhr and Mody, 1991a). Linear regression analyses showed average slope conductances of 49.6 $\pm 1.9 \mathrm{pS}(n=5)$ in control and $48.7 \pm 2.5 \mathrm{pS}(n=8)$ in kindled patches. Low-conductance substates seen with L-glutamate as an agonist (Gibb and Colquhoun, 1992) were rarely observed in our study, indicating that these low-conductance states may have been a result of activation of non-NMDA channels (cf. Gibb and Colquhoun, 1992). The NMDA single-channel conductances obtained in single-channel cell-attached recordings are consistently larger than the values of $20-35 \mathrm{pS}$ derived through fluctuation analysis of whole-cell NMDA noise (see 
CONTROL

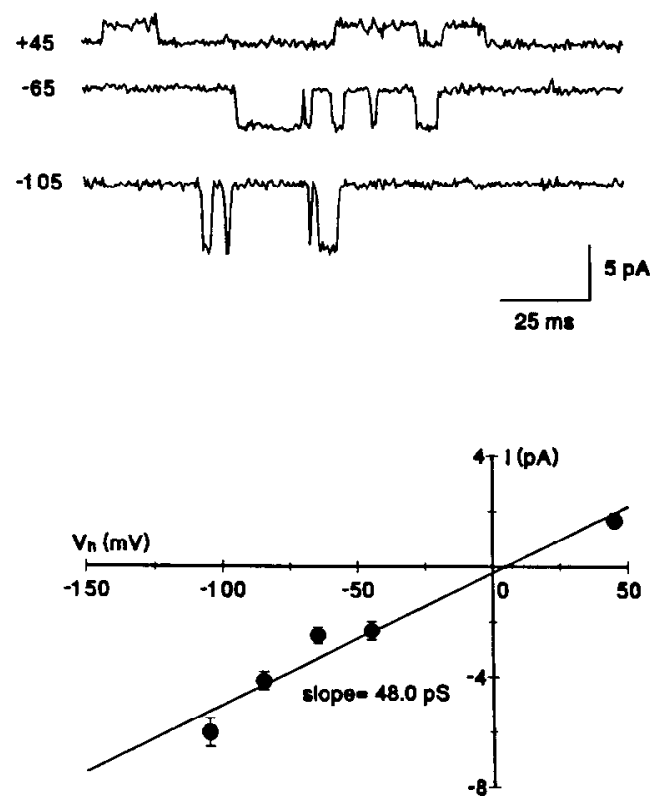

KINDLED

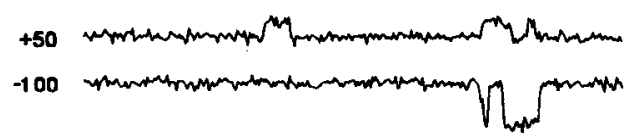

$-140$

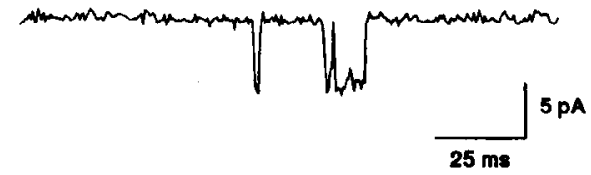

above, and Ascher et al., 1988). It is possible that the higher NMDA concentrations used in whole-cell experiments might have activated lower-conductance substates that may have contributed to the low values obtained in the whole-cell analysis (Cull-Candy and Usowicz 1989a,b).

\section{Shut time distributions}

Single-channel studies revealed the complex nature of openings and closings of NMDA channels (Ascher et al., 1988; Howe et al., 1988, 1991; Gibb and Colquhoun, 1991, 1992). Our analysis has shown that the distribution of shut times in 8 control and 14 kindled neurons where a sufficient number of closures $(>1000)$ were resolved for analysis, could be fitted by four or five exponential distributions (cf. Gibb and Colquhoun, 1991, 1992). The fifth exponential component was particularly evident in kindled neurons ( 5 of 14), whereas it was seen in only one of eight control cells at $10 \mu_{M}$ NMDA. Examples of the shut time distributions for a control and a kindled neuron recorded in the presence of $10 \mu \mathrm{M}$ NMDA are shown in Figure 7. The distribution means for shut times are given in Table 2 , and indicate a 30\% increase following kindling.

\section{Distribution of open times}

The distribution of apparent open times of $\geq 100 \mu \mathrm{sec}$ could be fitted with two or three exponential components (Fig. 7). Figure 7 also shows the distributions of open times in single openings in a control and a kindled neuron. As explained by Gibb and Colquhoun (1992), the fitted distributions clearly show a large fraction of short openings that are missed by the analysis. However, in the absence of any realistic description of an NMDA channel activation mechanism, at present no correction can be used for the missed events. As indicated in Table 2, the distribution mean of all openings to the main conductance state in kindled neurons was $163 \%$ of that in controls, while the duration of single openings was $158 \%$ of that observed in control neurons.
Figure 6. The single NMDA channel conductance does not change following kindling-induced epilepsy: cell-attached recordings in acutely isolated dentate gyrus granule cells of control and kindled rats using $10 \mu \mathrm{M}$ NMDA and $3 \mu \mathrm{M}$ glycine. Glycine was added in all experiments and will not be mentioned in the following figure captions. Following seal formation, the patches were held at various membrane potentials, and amplitude histograms of steady-state recordings $(2 \mathrm{~min})$ were constructed at potentials where a $50 \%$ threshold crossing method for automatic event detection could be used. Sample recordings from a control and a kindled neuron low-pass filtered at 1 $\mathrm{kHz}$ and digitized at $2 \mathrm{kHz}$ are shown at the top at the indicated $V_{h}$. Shown at the bottom are the respective $I / V$ relations of NMDA single channels constructed by linear regression of the current amplitude means (at each holding potential, error bars indicate SDs obtained from the Gaussian fits used to estimate the single-channel current in the patch). The slope conductance in five control cells varied between 45.1 and $56.6 \mathrm{pS}$ and in eight kindled cells ranged between 37.9 and $63.5 \mathrm{pS}$.
The total time that the channels spent open during bursts, clusters, or superclusters of openings (see below) was also fitted by the sum of three exponential distributions (Fig. 8). Each exponential component was prolonged in kindled neurons, but the most affected was the third, longest component of the total open times. As a result, the distribution means in kindled neurons (Table 2) were $206 \%, 233 \%$, and $327 \%$ of the control total open times per burst, cluster and supercluster, respectively.

The average number of openings per burst, cluster, and supercluster was also significantly larger in kindled neurons (Table 2). Thus, the vast increase in total open time during the complex openings of NMDA channels is a result of the combination between more channel openings and each opening having a longer duration.

\section{Bursts, clusters, and superclusters}

Bursts were defined as groups of openings, clusters as a group of bursts, and superclusters as a group of clusters that were each separated by gaps shorter than a critical duration (Gibb and Colquhoun, 1991, 1992). Critical closed times were calculated from shut time distributions as indicated in Materials and Methods.

The duration of bursts in control cells could be best fitted by two to three exponential components (e.g., Fig. 9). The kinetics of bursts correspond to those reported by Howe et al., (1991), and by Gibb and Colquhoun $(1991,1992)$. As expected from our results obtained by fluctuation analysis, kindled NMDA channels had prolonged burst components (Fig. 9). The average duration of bursts increased by $119 \%$ following kindling (Table 2). The same was true for clusters of channel openings which increased by $129 \%$ after kindling (Table 2) due to the prolongation of each individual exponential component (Fig. 9).

Single NMDA channels are also known to open in superclusters (Gibb and Colquhoun, 1992). The predominantly four exponential component shut time distributions in control neu- 


\section{Control}

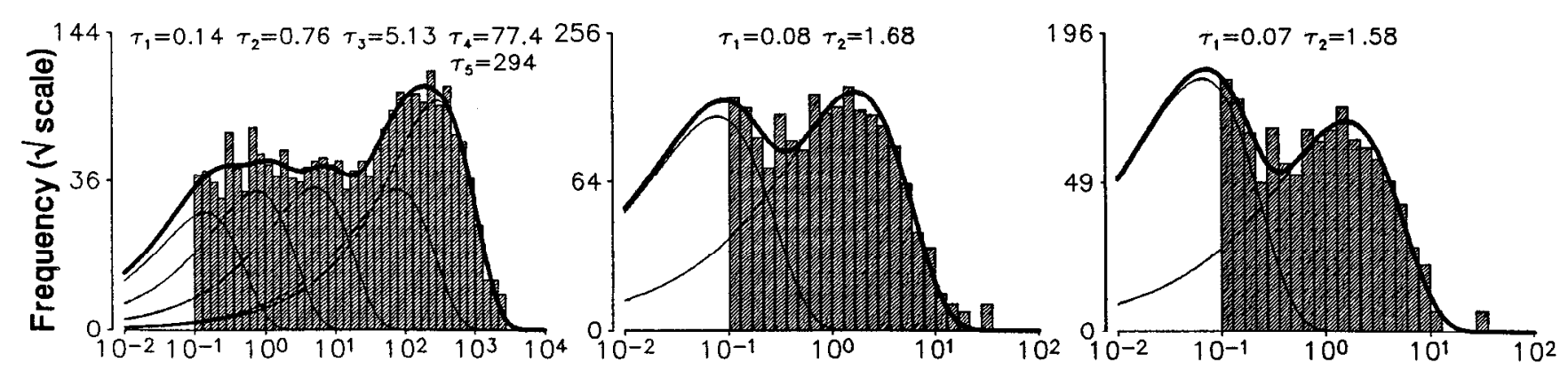

\section{Kindled}

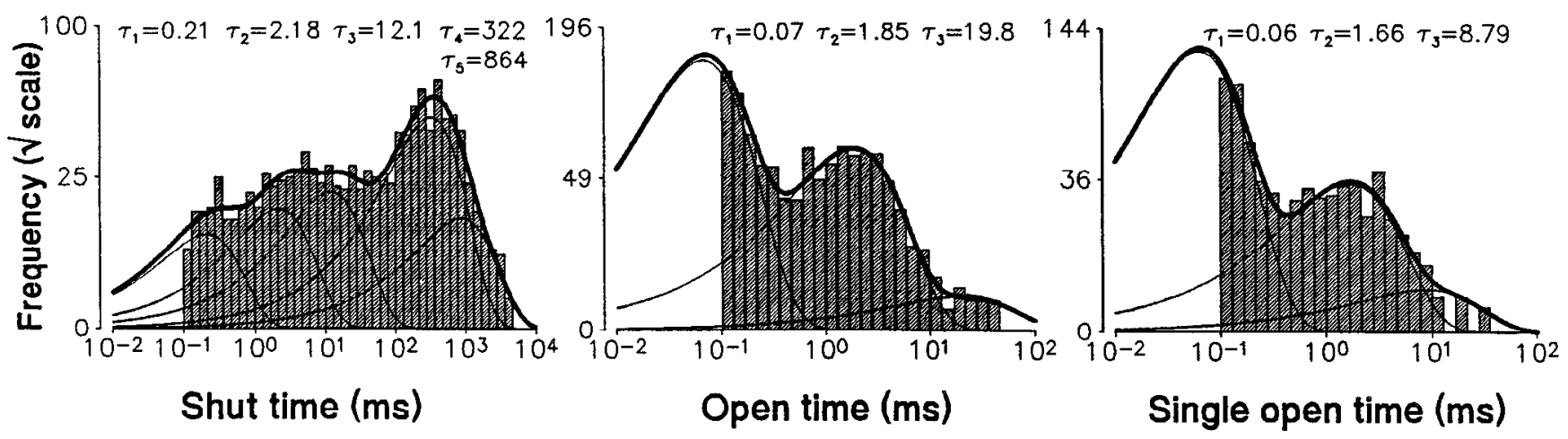

Figure 7. Shut time and open time distributions of NMDA channels in a control and a kindled neuron. In this and following figures, the recordings were done in the cell-attached mode using $10 \mu \mathrm{M}$ NMDA as agonist in the presence of $3 \mu \mathrm{M}$ glycine and the nominal absence of $\mathrm{Mg}^{2+}$, and dwell time distributions are plotted log-binned ( 9 bins/decade) on a square-root ordinate (Sigworth and Sine, 1987). The control shut time distribution (predicted number of events, 2397) is fitted with the sum of five exponential components (time constants are indicated in the figure) with the relative contributions of $11 \%, 15 \%, 16 \%, 17 \%$, and $42 \%$, respectively. The critical closed times for calculating burst, cluster, and supercluster durations were $1.2 \mathrm{msec}, 10.5 \mathrm{msec}$, and $97.7 \mathrm{msec}$, respectively. The five exponential components of the shut time distributions (predicted $n=$ 1272 ) in the kindled neuron have the relative areas of $9 \%, 15 \%, 19 \%, 45 \%$, and $12 \%$. The respective critical closed times were $3.19 \mathrm{msec}, 29.4 \mathrm{msec}$, and $352.4 \mathrm{msec}$. The distribution of all apparent openings longer than $100 \mu \mathrm{sec}$ was fitted with the sum of two exponentials (relative areas, $45 \%$ and $55 \%$ ) in the control neuron, and three exponentials (relative areas, $68 \%, 30 \%$, and $2 \%$ ) in the kindled neuron. The distribution of single openings longer than $100 \mu \mathrm{sec}$ was fitted with the sum of two exponentials (relative areas, $59 \%$ and $41 \%$ ) in the control neuron, and three exponentials (relative areas, $77 \%, 21 \%$, and $2 \%$ ) in the kindled neuron. In each plot the sum of the fitted distributions is indicated by a thick line, while individual distributions are shown as thinner lines.

rons precluded us from a detailed analysis of superclusters. In only one of the eight control granule cells $(12.5 \%)$ in which the number of openings satisfied our criteria for analysis could superclusters be determined, and this occurred at $10 \mu \mathrm{M}$ NMDA in the pipette (Figs. 7, 9; Table 2). In contrast, 5 out of 14 kindled neurons (35.7\%; one at $5 \mu \mathrm{M}$ NMDA and four cells at $10 \mu \mathrm{M}$ NMDA) showed clear five exponential component shut time distributions such that superclusters could be readily detected and analyzed (Fig. 9, Table 2). This may indicate the higher affinity for NMDA of kindled channels (Köhr and Mody, 1992), as superclusters can usually be detected in control preparations with higher-affinity agonists such as L-glutamate (Gibb and Colquhoun, 1992) or L-aspartate (D. Licbcrman and I. Mody, unpublished observations). As expected, the supercluster length in kindled neurons was considerably longer than that observed in the control cell. Furthermore, the value obtained in kindled granule cells (Table 2) was $255 \%$ of the mean supercluster duration $(90 \mathrm{msec})$ reported in CA1 pyramidal cells by Gibb and Colquhoun (1992).
Interestingly, the overall probability of channel openings in these complex groupings was not altered following kindling. However, the calculation of this probability is biased by the large number of individual single openings that are included in the analysis. Thus, the increased burst, cluster, and supercluster durations following kindling can be accounted for by the prolongation of the mean open time and the increase of the number of openings in a given grouping with multiple openings (Table 2).

\section{Discussion}

The results of the present study are consistent with a change in NMDA receptor structure or function during long-term in vivo neuronal plasticity produced by kindling. Thus, NMDA receptors not only participate in the generation of kindling (Peterson et al., 1983; Vezzani et al., 1988; Holmes et al., 1990), but also appear to be flexible by undergoing long-term modifications. Our analyses of single NMDA channels and whole-cell NMDA currents in dentate gyrus granule cells isolated from a chronically 
Table 2. Summary of mean dwell time values of NMDA channels activated by 1,5 , or $10 \mu M$ NMDA

in control and kindled neurons

\begin{tabular}{|c|c|c|c|c|}
\hline & Control & & Kindled & \\
\hline & Mean \pm SEM & $n$ & Mean \pm SEM & $n$ \\
\hline Shut time (msec) & $304.0 \pm 83.8$ & 8 & $394.5 \pm 56.3$ & 14 \\
\hline All openings (msec) & $1.26 \pm 0.15$ & 8 & $2.05 \pm 0.11^{*}$ & 14 \\
\hline Openings in bursts with 1 opening (msec) & $1.00 \pm 0.15$ & 8 & $1.58 \pm 0.10^{*}$ & 14 \\
\hline Openings in bursts with $\geq 2$ openings (msec) & $1.73 \pm 0.23$ & 8 & $2.42 \pm 0.14^{*}$ & 14 \\
\hline$p_{\text {open }}$ total $\left(\times 10^{-3}\right)$ & $6.4 \pm 2.0$ & 8 & $6.6 \pm 1.0$ & 14 \\
\hline Burst length (msec) & $1.91 \pm 0.12$ & 8 & $4.18 \pm 0.29^{*}$ & 14 \\
\hline Total open/burst (msec) & $1.63 \pm 0.17$ & 8 & $3.35 \pm 0.21^{*}$ & 14 \\
\hline Number of openings/burst & $1.30 \pm 0.03$ & 8 & $1.63 \pm 0.04^{*}$ & 14 \\
\hline$p_{\text {burst }}\left(\times 10^{-3}\right)$ & $7.3 \pm 2.0$ & 8 & $8.2 \pm 1.0$ & 14 \\
\hline Burst $p_{\text {open }}$ & $0.93 \pm 0.02$ & 8 & $0.91 \pm 0.01$ & 14 \\
\hline Cluster length (msec) & $9.11 \pm 1.78$ & 8 & $20.86 \pm 5.44^{*}$ & 14 \\
\hline Total open/cluster (msec) & $2.20 \pm 0.23$ & 8 & $5.12 \pm 0.38^{*}$ & 14 \\
\hline Number of openings/cluster & $1.77 \pm 0.06$ & 8 & $2.51 \pm 0.15^{*}$ & 14 \\
\hline$p_{\text {cluster }}\left(\times 10^{-3}\right)$ & $20 \pm 3$ & 8 & $24 \pm 4$ & 14 \\
\hline Cluster $p_{\text {open }}$ & $0.77 \pm 0.03$ & 8 & $0.73 \pm 0.02$ & 14 \\
\hline Supercluster length (msec) & 28.9 & 1 & $229.8 \pm 57.1$ & 5 \\
\hline Total open/supercluster (msec) & 3.87 & 1 & $12.64 \pm 1.92$ & 5 \\
\hline Number of openings/supercluster & 2.57 & 1 & $6.28 \perp 0.94$ & 5 \\
\hline$p_{\text {supercluster }}\left(\times 10^{-3}\right)$ & 76 & 1 & $161 \pm 43$ & 5 \\
\hline Supercluster $p_{\text {open }}$ & 0.62 & 1 & $0.40 \pm 0.05$ & 5 \\
\hline
\end{tabular}

Each asterisk denotes significant difference ( $p<0.05$, two-tailed $t$ test with correction for unequal variances) between values obtained in control and kindled neurons. The only superclusters of NMDA channel openings in a control neuron were obtained in the presence of $10 \mu \mathrm{M}$ NMDA.

epileptic preparation demonstrate specific changes in the biophysical properties of NMDA receptor channels. Kindling prolonged the duration of channel openings, bursts, and clusters; it altered the sensitivity of the channel to intracellular highenergy phosphates, and the voltage-dependent block exerted by $\mathrm{Mg}^{2+}$, but did not influence the rate of decay to steady state, or the single-channel conductance.

Recordings from single ligand-gated ion channels have clearly identified distinct molecular changes that affect the channel properties and occur as part of the normal process of developmental plasticity (e.g., Mishina et al., 1986; Sakmann et al., 1992). Perhaps similar to muscle ACh receptor channels, the prospect of alterations in the structure or function of NMDA channels during development has been raised by recent studies of developmental plasticity in the CNS (Carmignoto and Vicini, 1992; Hestrin, 1992). An altered divalent cation-dependent block of the channel during early postnatal development has already been shown in rat hippocampal neurons (Ben-Ari et al., 1989; Morrisett et al., 1990; Brady et al., 1991). A commensurate developmental alteration in NMDA channel function may be the selective loss of NMDA responsiveness in early postnatal cerebellar Purkinje cells compared to their embryonic counterparts. This may be taken as evidence for a selective downregulation of NMDA function during the maturation of these neurons (Garthwaite et al., 1987; Farrant and Cull-Candy, 1991). Yet, little is known about channcl properties during lasting physiological or pathological alterations of neuronal excitability in adult mammalian CNS neurons.

Two forms of such plasticity in adult neurons, LTP and kindling, share some common features mostly related to the activation of NMDA receptor channels. Induction of both LTP (Collingridge et al., 1983) and kindling (Peterson et al., 1983;
Vezzani et al., 1988; Holmes et al., 1990) critically depends on the activation of NMDA receptors. Furthermore, once plasticity is induced, there is a lasting augmentation of the NMDA receptor-mediated component of synaptic transmission during both LTP (Bashir et al., 1991; Xie et al., 1992) and kindling (Mody and Heinemann, 1987; Gean et al., 1989). To date, no single-channel correlates of such persistently enhanced NMDA receptor function have been reported for any adult form of neuronal plasticity. One could have chosen to examine the properties of NMDA channels during the maintenance phase of LTP, but while the enhanced synaptic activation of NMDA receptors during LTP may not be entirely of postsynaptic origin (cf. Baudry and Davis, 1991), kindling seems ideally suited for the study of NMDA channel-related alterations. The presynaptic changes during kindling (Jarvie et al., 1990) are unequivocally matched by an altered postsynaptic responsiveness to NMDA demonstrated in biochemical, pharmacological (Morrisett et al., 1989; Yeh et al., 1989; Martin et al., 1992), and electrophysiological studies (Mody and Heinemann, 1987; Gean et al., 1989). Moreover, as the epilepsy progressively becomes generalized, the number of synapses affected by kindling is likely to be large. Thus, a quite homogeneous population of isolated neurons, presumably affected by kindling in like manner, can be chosen for the study. Our findings in such population of nerve cells, the granule cells of the dentate gyrus, extend the recent advances on the developmental activity-dependent plasticity of NMDA receptors (Carmignoto and Vicini, 1992; Hestrin, 1992) to the fully differentiated adult mammalian CNS, where the behavior of NMDA receptors during chronic changes in neuronal excitability turns out to be just as plastic. Previous physiological studies could not readily discriminate between the pre- or postsynaptic origins of the enhancement in NMDA receptor-related 


\section{Control}
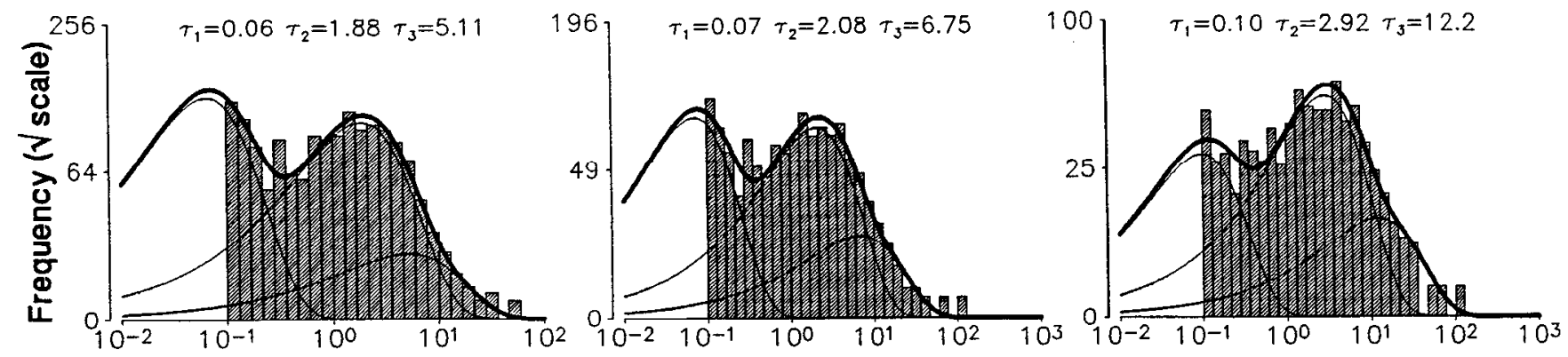

\section{Kindled}
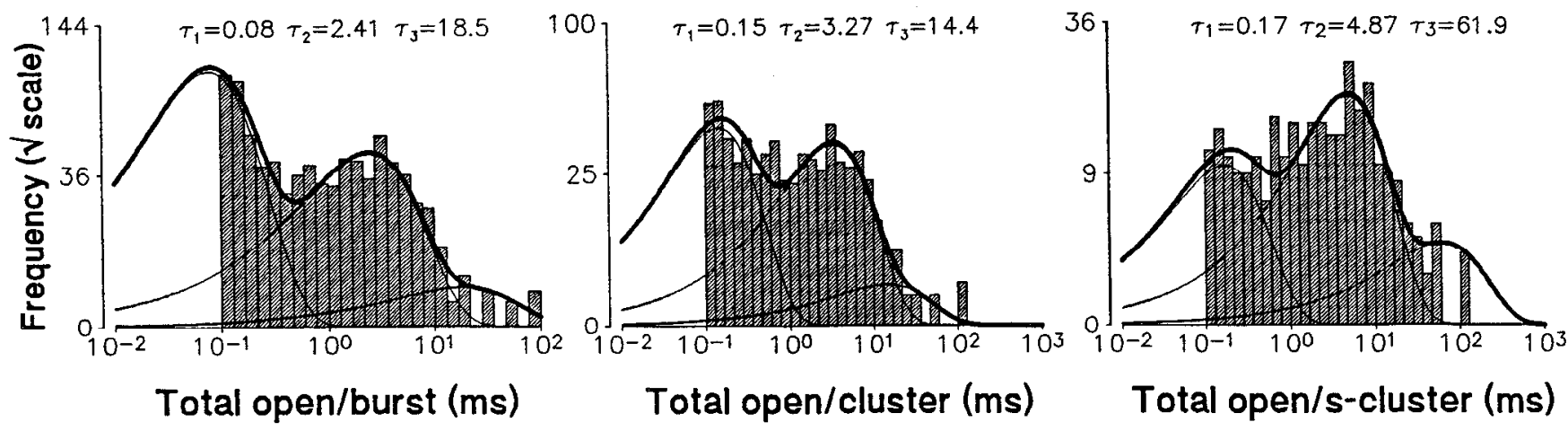

Figure 8. The distribution of total open times of NMDA channels during a burst, cluster, and supercluster analyzed in the control and kindled neurons illustrated in Figure 7. The distribution of the sum of all apparent openings during a burst was fitted with the sum of three exponentials in both the control (relative areas, $53 \%, 42 \%$, and $5 \%$ ) and the kindled neuron (relative areas, $67 \%, 31 \%$, and $2 \%$ ). Similarly, the distribution of the sum of all apparent openings during a cluster was fitted with the sum of three exponentials in the control (relative areas, $49 \%$, $43 \%$, and $8 \%$ ) and the kindled neuron (relative areas, $53 \%, 44 \%$, and 3\%). The sum of openings during a supercluster was also fitted with the sum of three exponentials in the control (relative areas, $31 \%, 57 \%$, and $12 \%$ ) and kindled neuron (relative areas, $30 \%, 62 \%$, and $8 \%$ ). Note the prolongation of each individual time constant for every distribution in the kindled neuron.

excitability following kindling. Our findings do not exclude the possibility of an increased glutamate release partially boosting neuronal excitability after kindling (Jarvie et al., 1990), but clearly demonstrate several functional alterations of postsynaptic NMDA receptor channels as direct correlates of neuronal plasticity in the adult CNS.

Whole-cell NMDA responses. First, the basic properties of adult granule cell NMDA channels obtained in whole-cell recordings were compared to those already known from other systems. Akin to wholc-cell NMDA currents recorded in cultured neurons, NMDA responses of acutely isolated granule cells were potentiated by extracellular glycine (Johnson and Ascher, 1987) and decayed in a $\mathrm{Ca}^{2+}$-dependent manner (Clark et al., 1990; Vyklicky et al., 1990; Legendre et al., 1993). The noise spectra of steady-state NMDA currents were best described by the sum of two Lorentzians, which is in contrast to spectra obtained in cultured hippocampal or spinal cord neurons (Ascher et al., 1988; Mayer et al., 1988), but is in good agreement with whole-cell recordings in cerebellar neurons (Cull-Candy et al., 1988; Cull-Candy and Usowicz, 1989a) and NMDA-activated outside-out patches (Cull-Candy and Usowicz, 1989b). Although the acutely dissociated cells in our study were exposed from most sides to the bathing solution and three or four thor- ough washes in nominally $\mathrm{Mg}^{2+}$-free medium were carried out before recording, it is still possible that the double Lorentzian spectra reflect the presence of some residual $\left[\mathrm{Mg}^{2+}\right]_{v}$ (Mayer et al., 1988; Gibb and Colquhoun, 1992). The conductance derived from fluctuation analysis of whole-cell NMDA currents in our preparation was comparable to the values obtained through similar methods in cultured neurons (Ascher et al., 1988; CullCandy et al., 1988; Mayer et al., 1988; Cull-Candy and Usowicz, 1989a).

In light of the similarities between whole-cell NMDA responses recorded in acutely dissociated granule cells and in various other preparations (Ascher et al., 1988; Cull-Candy et al., 1988; Mayer et al., 1988; Cull-Candy and Usowicz, 1989a; LoTurco et al., 1990), it is unlikely that the enzymatic dissociation procedure had any deleterious effects on NMDA receptor channels. Thus, changes in the function of NMDA receptors of kindled acutely dissociated granule cells are extremely unlikely to result from a differential sensitivity of kindled NMDA channels to pronase treatment. The observed modifications in the biophysical properties of NMDA channels in kindled neurons must reflect a chronic plasticity-related alteration in channel function. The alterations in NMDA channel properties are but one aspect of the complex cellular correlates of kindling-induced 


\section{Control}
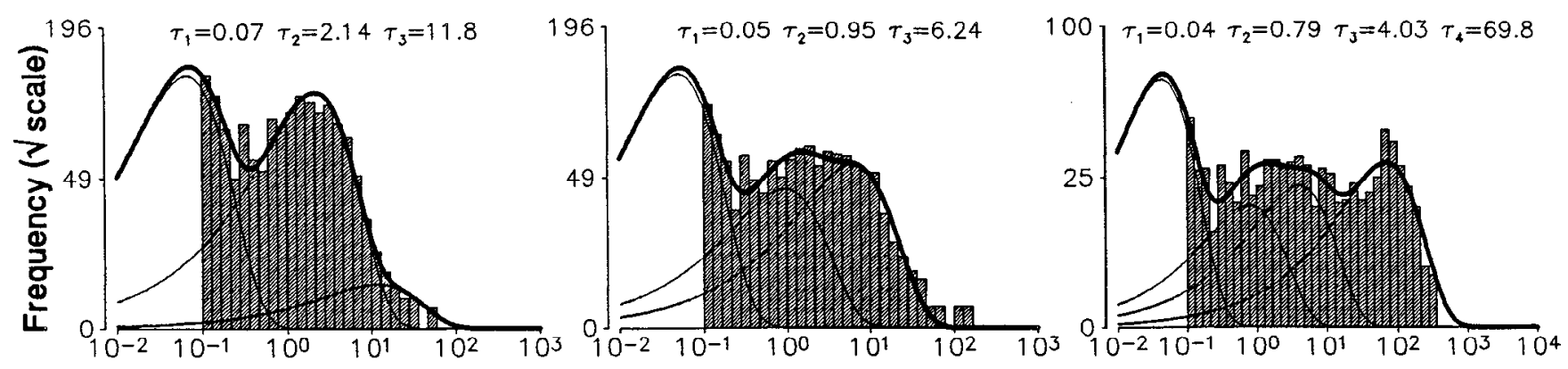

\section{Kindled}
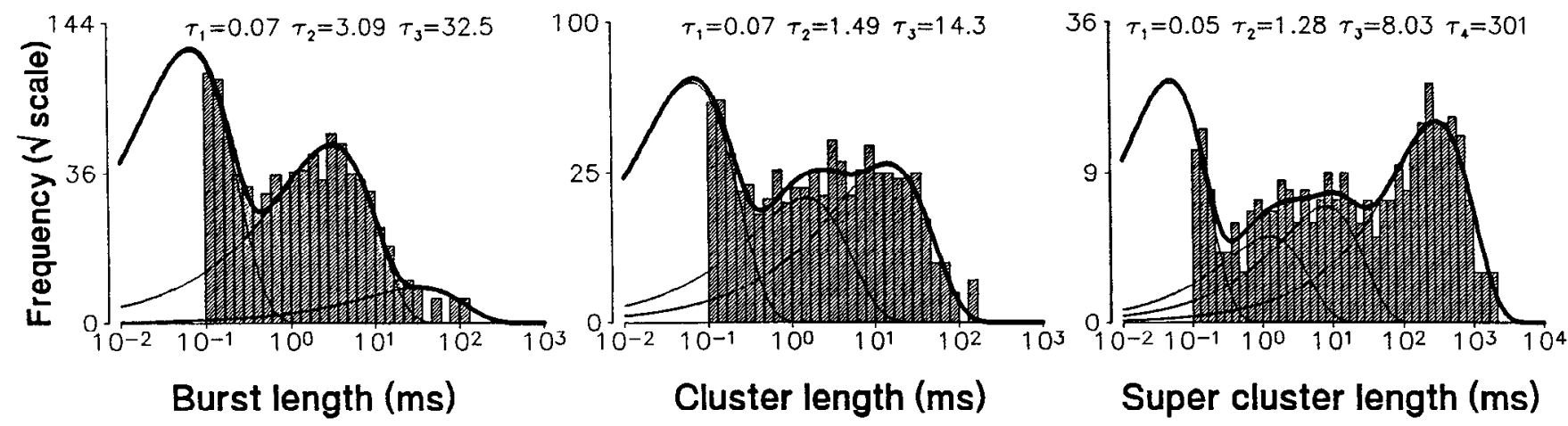

Figure 9. The distribution of burst, cluster, and supercluster durations in a control and a kindled neuron, plotted as described in Figure 7. These groupings of openings were separated on the basis of critical closed limes calculated as indicated in the caption of Figure 7 from the distribution of all shut times. The distributions of bursts and clusters were fitted with the sum of three exponentials (values are indicated in the figures) in both the control and the kindled neuron. The relative areas for bursts were $53 \%, 45 \%$, and $2 \%$ for the control neuron, and $68 \%, 30 \%$, and $2 \%$ for the kindled neuron. The relative areas for clusters were $58 \%, 18 \%$, and $24 \%$ for the control neuron, and $58 \%, 16 \%$, and $26 \%$ for the kindled neuron. The distribution of superclusters was fitted with the sum of four exponential components with the relative areas of $50 \%, 12 \%, 16 \%$, and $22 \%$ in the control neuron and $48 \%, 6 \%, 11 \%$, and $34 \%$ in the kindled neuron. Again, the prolongation of each individual time constant in every distribution is evident in the kindled neuron. Data are from the same two neurons as in Figure 7.

neuronal plasticity. We have previously demonstrated kindled neurons to have different high-voltage-activated calcium current kinetics (Köhr and Mody, 1991a; Köhr et al., 1991) resulting from the loss of the intraneuronal calcium-binding protein calbindin $\mathrm{D}_{28 \mathrm{~K}}$.

The distinguishing features of kindled whole-cell NMDA responses in the nominal absence of $\mathrm{Mg}^{2+}$ were their enhanced sensitivity to intracellular high-energy phosphates and their roughly $50-60 \%$ longer lifetimes. In whole-cell recordings, if no high-energy phosphates are included in the recording pipette, NMDA currents evoked in cultured hippocampal or retinal neurons run down by about $50 \%$ with a time constant of approximately 2 min (MacDonald et al., 1989; Nawy and Jahr, 1990). Analogous to the rundown of voltagc-dependent $\mathrm{Ca}^{2+}$ channels in whole-cell recordings (e.g., see Chad and Eckert, 1986), this finding has been taken as evidence for the intracellular regulation of NMDA receptor channels by phosphorylation (MacDonald et al., 1989). Our original hypothesis was that if kindling induced a different state of phosphorylation of NMDA channels, then whole-cell NMDA currents should run down at different rates in control versus kindled neurons. Yet, recorded in the absence of an intracellular ATP regeneration system, NMDA currents of acutely dissociated granule cells (whether control or kindled) did not run down during our recordings (up to $90 \mathrm{~min}$ ). We attribute this to the small volume of the dissociated granule cells. As the diffusion of intracellular constituents is dependent on cell volume (Pusch and Neher, 1988), NMDA responses may have rapidly run down during the first minute of whole-cell recordings while adjustments to the clamp and perfusion system were made.

If such a rapid rundown was responsible for the lack of timedependent changes in the amplitude of NMDA currents during whole-cell recordings in control neurons, then recordings in the presence of an intracellular high-energy phosphate support system should have yielded significantly larger-amplitude currents (Forscher and Oxford, 1985; Gyenes et al., 1988; Stelzer et al., 1988; MacDonald et al., 1989). This, however, was not the case in control granule cells, implying the existence of a basal, dephosphorylated state of the NMDA channels. In contrast, kindled granule cells, like embryonic cultured neurons, had considerably smaller-amplitude NMDA currents in the absence of high-energy phosphates. This high sensitivity of kindled NMDA channels to the presence of an intracellular high-energy phosphate system may stem from the existence of predominantly 
phosphorylated NMDA channels following kindling or from the appearance of a novel NMDA channel type that requires phosphorylation for full functional expression. For example, during kindling, the insertion of a $\zeta$ l subunit that appears to be positively modulated by protein kinase $C$ (Yamazaki et al., 1992) may provide a differential modulation of kindlcd NMDA rcceptors.

Since whole-cell NMDA currents are a function of the number of channels, single-channel conductance, and the channel opening probability, any of these three parameters might have been altered after kindling. Pharmacological studies after kindling have shown that the number of NMDA binding sites are not significantly altered (Jones and Johnson, 1989; Okazaki et al., 1989) or are slightly increased (Yeh et al., 1989) with a dramatic gain in the potency of NMDA in CA3 neurons (Martin et al., 1992). Our present findings show that single-channel conductance is not altered by kindling, but at least some kindled NMDA channels are markedly different from their control counterparts. Unlike control NMDA channels, which may not be fully phosphorylated, the phosphorylated kindled channels may have significantly lower opening probability upon dephosphorylation (i.c., in the absence of high-energy phosphates).

In kindled neurons, a strong correlation was found between the prevalent open times of NMDA channels and the corresponding peak NMDA currents. Only small-amplitude NMDA currents could be evoked in the absence of ATP, regardless of the mean open times of the dominant NMDA channels (either 4.5 or $7.0 \mathrm{msec}$ ). If however, kindled neurons were intracellularly perfused with the ATP regeneration system, NMDA channels predominantly open for $7.0 \mathrm{msec}$ produced small NMDA currents but neurons with NMDA channels predominantly open for $4.5 \mathrm{msec}$ showed larger than control NMDA responses. The differential effect of the ATP regeneration system on NMDA currents suggests that channels with short lifetimes $(4.5 \mathrm{msec})$ are more dependent on phosphorylation in kindled than in control neurons, and that channels with a longer lifetime $(7.0 \mathrm{msec}$; only present in kindled neurons) are unaffected by the addition of intracellular high-energy phosphates.

Single NMDA channels. The recent comprehensive characterization of NMDA channels in acutely isolated CA 1 neurons (Gibb and Colquhoun, 1991, 1992) revealed complex kinetics of these channels that were quite different from the kinetics of the well-characterized ACh receptor channels. NMDA channels have high-activity periods defined as bursts, clusters, and superclusters separated by long shut periods. We have obtained similar results in adult granule cells dissociated from control animals. The open and shut time resolutions (100 and $50 \mu \mathrm{sec}$, respectively) of our study preclude us from accurately comparing very fast channel kinetics to those reported by Gibb and Colquhoun (1992), yet the overall distribution of various dwell times was quite similar to that reported by these authors. The only notable exception is the lack of superclusters in all but one of the control granule cells (cf. Gibb and Colquhoun, 1992). This may be a consequence of using a lower-affinity agonist (NMDA) in the present study. Then the fact that more kindled neurons showed superclusters at $10 \mu \mathrm{M}$ NMDA would indicate a higher sensitivity to NMDA of kindled channels. This possibility has been confirmed using cell-attached dose-response studies in control and kindled neurons (Köhr and Mody, 1992; G. Köhr and I. Mody, unpublished observations).

As the very factors responsible for the long-term alterations of NMDA channels may reside in the cytoplasm or on the cytoplasmic side of the membrane, and some of these factors may be critically influenced by the recording configuration, we have solely relied upon the comparison of cell-attached recordings in control and kindled neurons. Indeed, our recordings have consistently shown an approximate doubling of the mean open times, burst, and cluster durations in kindled neurons, but no change in single-channel conductance. This confirms the findings of longer NMDA channel lifetime and unaltered conductance derived from fluctuation analysis of whole-cell NMDA currents.

It is interesting to consider the possibility that the prolonged openings of kindled NMDA channels may be a consequence of the altered $\mathrm{Mg}^{2+}$ sensitivity of whole-cell NMDA currents. As pointed out by Gibb and Colquhoun (1992), the small residual $\mathrm{Mg}^{2+}$ concentration $(\approx 4 \mu \mathrm{M})$ present in the nominally $\mathrm{Mg}^{2+}$ free recording solution may significantly affect the openings of NMDA channels. However, the calculated affinity for $\mathrm{Mg}^{2+}$ of kindled NMDA channels at membrane potentials where the cellattached recordings have been made is actually higher than that of control channels (see above). Thus, kindled NMDA channels open longer in spite of an increased possible residual $\mathrm{Mg}^{2+}$ block at hyperpolarized potentials.

Presently there is no detailed and unequivocal kinetic description of the complex behavior of NMDA channels. Therefore, we will refrain from speculating on the relationship of the several open and shut states to the actual channel activation mechanism and its alteration by kindling. It is, however, unlikely that the reported increase in glycine sensitivity following kindling (Yeh et al., 1989) may play a significant role in the altered channel kinetics observed in our study. Namely, all of our recordings have been done in the presence of saturating glycine concentrations $(3 \mu \mathrm{M})$.

Possible mechanism and significance for upregulation of NMDA channels following kindling. The whole-cell recordings in our study were done in the absence of exogenous intracellular $\mathrm{Ca}^{2+}$ chelators. We have previously shown that this condition accurately mimics the intracellular $\mathrm{Ca}^{2+}$ sequestration capacity of acutely dissociated ncurons (Köhr and Mody, 1991a). As during the process of kindling, granule cells lose the cytoplasmic $\mathrm{Ca}^{2+}$ binding protein calbindin $\mathrm{D}_{28 \mathrm{~K}}$ (Miller and Baimbridge, 1983; Köhr et al., 1991) but retain normal levels of calmodulin (Miller and Baimbridge, 1983), we have previously speculated that calmodulin-mediated processes may be favored in kindled neurons (Köhr and Mody, 1991a). There are conflicting findings regarding the role of intracellular calcium in the regulation of NMDA receptor channels. Both a calcium-dependent enhancement (Markram and Segal, 1991, 1992) and inactivation (Legendre at al., 1993) of NMDA receptor function have been found in hippocampal neurons. If the calcium-dependent desensitization of NMDA responses in granule cells also critically depends on intracellular calcium buffering as shown for cultured hippocampal neurons (Legendre et al., 1993), one would expect the rate of desensitization in the presence of extracellular $\mathrm{Ca}^{2+}$ to be different in control and kindled neurons since intrancuronal calcium buffering is profoundly impaired in kindled cells (Köhr and Mody, 1991a). As this was clearly not the case, we must assume that the loss of calbindin $D_{28 \mathrm{~K}}$ and the ensuing reduction in intraneuronal calcium-buffering capacity following kindling have a negligible effect on kindled NMDA channels. However, as calmodulin and calbindin $D_{28 \mathrm{~K}}$, two calcium-binding proteins with similar affinities for $\mathrm{Ca}^{2+}$ of which only calbindin $\mathrm{D}_{28 \mathrm{~K}}$ is lost during kindling (Miller and Baimbridge, 1983), may com- 
pete for $\mathrm{Ca}^{2+}$ entering the neurons, the loss of a competitor protein (calbindin $\mathrm{D}_{28 \mathrm{~K}}$ ) may lead to an increase in autophosphorylated ( $\mathrm{Ca}^{2+}$-independent) calmodulin kinase II (CaMK II) as we have observed in the kindled dentate gyrus (K. Occor, $\mathrm{G}$. Köhr, H. Schulman, and I. Mody, unpublished observations). It is therefore conceivable that CaMK II-dependent processes may be responsible, at least in part, for the functional alterations of NMDA channels observed after kindling. Other kinases, such as the cAMP-dependent protein kinase, do not appear to include NMDA receptors as substrates (Greengard et al., 1991; Wang et al., 1991) but protein kinase $C$ has recently been shown to alter NMDA responses (Chen and Huang, 1991, 1992; Yamazaki et al., 1992) and thus may be a candidate for the upregulation of NMDA receptor function during kindling. It is presently unclear how the altered intracellular regulatory mechanisms may be responsible for the more complex $\mathrm{Mg}^{2+}$ block following kindling. Nevertheless, the steeper voltage-dependent activation of NMDA conductance in physiological $\left[\mathrm{Mg}^{2+}\right]_{0}$ will render kindled granule cells more easily depolarized by NMDA agonists once a critical voltage threshold is reached. As NMDA receptors are activated by low levels of ambient glutamate (Sah et al., 1989; LoTurco et al., 1990), any depolarizing influence will more readily activate NMDA receptors of kindled neurons than those of controls.

In contrast to changes in muscle $\mathrm{ACh}$ receptor channels during development (Mishina et al., 1986; Sakmann et al., 1992), all alterations of NMDA channels following kindling occur without a change in single-channel conductance. Nevertheless, it is possible that subtle molecular changes in the structure of NMDA receptor channels affecting their sensitivity to $\mathrm{Mg}^{2+}$ (Burnashev et al., 1992a; Mori et al., 1992), and kinetics of openings may occur during kindling possibly through genetic or RNA-editing mechanisms such as described for AMPA receptors (Burnashev et al., 1992b). We are presently investigating how the prolonged lifetime of single NMDA channels translates into the duration of synaptic currents in kindled neurons. It would be expected that the enhanced burst and cluster duration of NMDA channels could significantly prolong the NMDA component of the excitatory synaptic events (Lester et al., 1990; Gibb and Colquhoun, 1992) and thus may ultimately contribute to the enhanced synaptic excitability in the chronically epileptic brain. In light of the recent findings of Carmignoto and Vicini (1992) describing the activity-dependent downregulation of NMDA receptormediated synaptic currents in cortical neurons, our present study supports the hypothesis that the converse occurs in the fully mature brain following excessive neuronal activity associated with the progression of epileptogenesis.

\section{References}

Aizenman E, Lipton SA, Loring RH (1989) Selective modulation of NMDA responses by reduction and oxidation. Neuron 2:1257-1263.

Ascher P, Nowak L (1988) The role of divalent cations in the $N$-methyl-D-aspartate responses of mouse central neurones in culture. J Physiol (Lond) 399:247-266.

Ascher P, Bregestovski P, Nowak L (1988) N-methyl-D-aspartateactivated channels of mouse central neurones in magnesium-free solutions. J Physiol (Lond) 399:207-226.

Barlow R (1990) Cumulative frequency curves in population analysis. Trends Pharmacol Sci 11:404-406.

Bashir ZI, Alford S, Davies SN, Randall AD, Collingridge GL (1991) Long-term potentiation of NMDA receptor-mediated synaptic transmission in the hippocampus. Nature 349:156-158.

Baudry M, Davis JL, eds (1991) Long-term potentiation. A debate of current issues. Cambridge, MA: MIT Press.
Ben- $\Lambda$ ri $Y$, ed (1990) Advances in experimental medicine and biology, Vol 268, Excitatory amino acids and neuronal plasticity. New York: Plenum.

Ben-Ari Y, Cherubini E, Corradetti R, Gaiarsa JL (1989) Giant synaptic potentials in immature rat $\mathrm{CA} 3$ hippocampal neurones. J Physiol (Lond) 416:303-325.

Brady RJ, Smith KL, Swann JW (1991) Calcium modulation of the $N$-methyl-D-aspartate (NMDA) response and electrographic seizures in immature hippocampus. Neurosci Lett 124:92-96.

Burnashev N, Schoepfer R, Monyer H, Ruppersberg JP, Günther W, Seeburg PH, Sakmann B (1992a) Control by asparagine residues of calcium permeability and magnesium blockade in the NMDA receptor. Science 257:1415-1419.

Burnashev N, Monyer H, Seeburg PH, Sakmann B (1992b) Divalent ion permcability of AMPA receptor channcls is dominated by the edited form of a single subunit. Neuron 8:189-198.

Caceci MS, Cacheris WP (1984) Fitting curves to data: the Simplex algorithm is the answer. Byte 9:340-362.

Carmignoto G, Vicinis (1992) Activity-dependent decrease in NMDA receptor responses during development of the visual cortex. Science 258:1007-1011.

Chad JE, Eckert R (1986) An enzymatic mechanism for calcium current inactivation in dialyzed Helix neurones. J Physiol (Lond) 378: 31-51.

Chen L, Huang L-YM (1991) Sustained potentiation of NMDA receptor-mediated glutamate responses through activation of protein kinase $C$ by a $\mu$ opioid. Neuron 7:319-326.

Chen L, Huang L-YM (1992) Protein kinase C reduces $\mathrm{Mg}^{2+}$ block of NMDA receptor-channels as a mechanism of modulation. Nature 356:521-523.

Clark GD, Clifford DB, Zorumski CF (1990) The effect of agonist concentration, membrane voltage and calcium on $N$-methylD-aspartate receptor desensitization. Neuroscience 39:787-797.

Collingridge GL, Kehl SJ, McLennan H (1983) Excitatory amino acids in synaptic transmission in the Schaffer collateral-commissural pathway of the rat hippocampus. J Physiol (Lond) 334:33-46.

Colquhoun D, Hawkes AG (1990) Stochastic properties of ion channel openings and bursts in a membrane patch that contains two channels: evidence concerning the number of channels present when a record containing only single openings is observed. Proc R Soc Lond [Biol] 240:453-477.

Colquhoun D, Sakmann B (1985) Fast events in single-channel currents activated by acetylcholine and its analogues at the frog muscle endplate. J Physiol (Lond) 369:501-557.

Cull-Candy SG, Usowicz MM (1989a) Whole-cell current noise produced by excitatory and inhibitory amino acids in large cerebellar neurones of the rat. J Physiol (Lond) 415:533-553.

Cull-Candy SG, Usowicz MM (1989b) On the multiple-conductance single channels activated by excitatory amino acids in large cerebellar neurones of the rat. J Physiol (Lond) 415:555-582.

Cull-Candy SG, Howe IR, Ogden DC (1988) Noise and single channels activated by excitatory amino acids in rat cerebellar granule neurones. J Physiol (Lond) 400:189-222.

Farrant M, Cull-Candy SG (1991) Excitatory amino acid receptorchannels in Purkinje cells in thin cerebellar slices. Proc R Soc Lond [Biol] 244:179-184.

Forscher P, Oxford GS (1985) Modulation of calcium channels by norepinephrine in internally dialyzed avian sensory neurons. J Gen Physiol 85:743-763.

Garthwaite G, Yamini B, Garthwaite J (1987) Selective loss of Purkinje and granule cell responsiveness to $N$-methyl-D-aspartate in rat cerebellum during development. Dev Brain Res 36:288-292.

Gean PW, Shinnick-Gallagher P, Anderson AC (1989) Spontaneous epileptiform activity and alteration of GABA- and of NMDA-mediated neurotransmission in amygdala neurons kindled in vivo. Brain Res 494:177-181.

Gibb AJ, Colquhoun D (1991) Glutamate activation of a single NMDA receptor-channel produces a cluster of channel openings. Proc R Soc Lond [Biol] 243:39-45.

Gibb AJ, Colquhoun D (1992) Activation of $N$-methyl-D-aspartate receptors by $L$-glutamate in cells dissociated from adult rat hippocampus. J Physiol (Lond) 456:143-179.

Greengard P, Jen J, Nairn AC, Stevens CF (1991) Enhancement of the glutamate response by cAMP-dependent protein kinase in hippocampal neurons. Science 253:1135-1138. 
Gyenes M, Farrant M, Farb DH (1988) Run-down of $\gamma$-aminobutyric acid $_{\mathrm{A}}$ receptor function during whole-cell recording: a possible role for phosphorylation. Mol Pharmacol 34:719-723.

Hamill OP, Marty A, Neher E, Sakmann B, Sigworth FJ (1981) Improved patch-clamp techniques for high-resolution current recording from cells and cell-free membrane patches. Pfluegers Arch 391:85100.

Hestrin S (1992) Developmental regulation of NMDA receptor-mediated synaptic currents at a central synapse. Nature 357:686-689.

Hille B, Schwarz W (1978) Potassium channels as multi-ion singlefile pores. J Gen Physiol 72:409-442.

Holmes KH, Bilkey DK, Laverty R, Goddard GV (1990) The $N$-methyl-D-aspartate antagonists aminophosphonovalerate and carboxypiperazinephosphonate retard the development and expression of kindled seizures. Brain Res 506:227-235.

Howe JR, Colquhoun D, Cull-Candy SG (1988) On the kinetics of large-conductance glutamate-receptor ion channels in rat cerebellar granulc ncurons. Proc R Soc Lond [Biol] 233:407-422.

Howe JR, Cull-Candy SG, Colquhoun D (1991) Currents through single glutamate receptor channels in outside-out patches from rat cerebellar granule cells. J Physiol (Lond) 432:143-202.

Huganir RL, Greengard P (1983) cAMP-dependent protein kinase phosphorylates the nicotinic acetylcholine receptor. Proc Natl Acad Sci USA 80:1130-1134.

Jahr CE, Stevens CF (1990a) A quantitative description of NMDA receptor-channel kinetic behavior. J Neurosci 10:1830-1837.

Jahr CE, Stevens CF (1990b) Voltage dependence of NMDA-activated macroscopic conductances predicted by single-channel kinetics. J Neurosci 10:3178-3182.

Jarvie PA, Logan TC, Geula C, Slevin JT (1990) Entorhinal kindling permanently enhances $\mathrm{Ca}^{2+}$-dependent $\mathrm{L}$-glutamate release in regio inferior of rat hippocampus. Brain Res 508:188-193.

Johnson JW, Ascher P (1987) Glycine potentiates the NMDA response in cultured mouse brain neurons. Nature 325:529-531.

Johnson JW, Ascher P (1990) Voltage-dependent block by intracellular $\mathrm{Mg}^{2+}$ of $N$-methyl-D-aspartate-activated channels. Biophys J 57:10851090.

Jones SM, Johnson KM (1989) Effects of amygdaloid kindling on NMDA receptor function and regulation. Exp Neurol 106:52-60.

Köhr G, Mody I (1991a) Endogenous intracellular calcium buffering and the activation/inactivation of HVA calcium currents in rat dentate gyrus granule cells. J Gen Physiol 98:941-967.

Köhr G, Mody I (1991b) Increased requirement for high-energy phosphates by NMDA-receptors in acutely dissociated kindled granule cells. Soc Neurosci Abstr 17:1168.

Köhr G, Mody I (1992) Cell-attached recordings of NMDA channels in chronically epileptic (kindled) neurons. Soc Neurosci Abstr 18:978.

Köhr G, Lambert CE, Mody I (1991) Calbindin-D28K (CaBP) levels and calcium currents in acutely dissociated epileptic neurons. Exp Brain Res 85:543-551.

Kutsuwada T, Kashiwabuchi N, Mori H, Sakimura K, Kushiya E, Araki K, Meguro H, Masaki $H$, Kumanishi T, Arakawa M, Mishina $M$ (1992) Molecular diversity of the NMDA receptor channel. Nature 358:36-41.

Legendre P, Rosenmund C, Westbrook GL (1993) Inactivation of NMDA channels in cultured hippocampal neurons by intracellular calcium. J Neurosci 13:674-684.

Lester RA, Clements JD, Westbrook GL, Jahr CE (1990) Channel kinetics determine the time course of NMDA receptor-mediated synaptic currents. Nature 346:565-567.

LoTurco JJ, Mody I, Kriegstein AR (1990) Differential activation of glutamate receptors by spontaneously released transmitter in slices of neocortex. Neurosci Lett 114:265-271.

MacDonald JF, Mody I, Salter MW (1989) Regulation of $N$-methyl$\mathrm{D}$-aspartate receptors revealed by intracellular dialysis of murine neurones in culture. J Physiol (Lond) 414:17-34.

Markram H, Segal M (1991) Calcimycin potentiates responses of rat hippocampal neurons to $N$-methyl-D-aspartate. Brain Res 540:322324.

Markram H, Segal M (1992) The inositol 1,4,5,-trisphosphate pathway mediates cholinergic potentiation of rat hippocampal neuronal responses to NMDA. J Physiol (Lond) 447:513-533.

Martin D, McNamara JO, Nadler JV (1992) Kindling enhances sensitivity of CA3 hippocampal pyramidal cells to NMDA. J Neurosci 12:1928-1935.
Masukawa LM, Higashima M, Kim JH, Spencer DD (1989) Epileptiform discharges evoked in hippocampal brain slices from epileptic patients. Brain Res 493:168-174.

Mayer ML, Westbrook GL (1987) Permeation and block of $N$-methylD-aspartic acid receptor channels by divalent cations in mouse cultured central neurones. J Physiol (Lond) 394:501-527.

Mayer ML, Westbrook GL, Vyklicky L JI (1988) Sites of antagonist action of $N$-methyl-D-aspartic acid receptors studied using fluctuation analysis and a rapid perfusion technique. $J$ Neurophysiol 60:645-663.

McLarnon JG, Curry K (1990) Single channel properties of the $N$-methyl-D-aspartate receptor channel using NMDA and NMDA agonists: on-cell recordings. Exp Brain Res 82:82-88.

Miller JJ, Baimbridge KG (1983) Biochemical and immunohistochemical correlates of kindling-induced epilepsy: role of calcium binding protein. Brain Res 278:322-326.

Mishina M, Takai T, Imoto K, Noda M, Takahashi T, Numa S, Methfessel C, Sakmann B (1986) Molecular distinction between fetal and adult forms of muscle acetylcholine receptor. Nature 321:406-411.

Mody I, Heinemann U (1987) NMDA receptors of dentate gyrus granule cells participate in synaptic transmission following kindling. Nature 326:701-704.

Mody I, Saiter MW, MacDonald JF (1989) Whole-cell voltage-clamp recordings in granule cells acutely isolated from hippocampal slices of adult or aged rats. Neurosci Lett 93:70-75.

Monyer H, Sprengel R, Schoepfer R, Herb A, Higuchi M, Lomeli H, Burnashev N, Sakmann B, Seeburg PH (1992) Heteromeric NMDA receptors: molecular and functional distinction of subtypes. Science 256:1217-1221.

Mori H, Masaki H, Yamakura T, Mishina M (1992) Identification by mutagenesis of a $\mathrm{Mg}^{2+}$-block site of the NMDA receptor channel. Nature 358:673-675.

Morrisctt RA, Chow C, Nadler JV, McNamara JO (1989) Biochemical evidence for enhanced sensitivity to $N$-methyl-D-aspartate in the hippocampal formation of kindled rats. Brain Res 496:25-28.

Morrisett RA, Mott DD, Lewis DV, Wilson WA, Swartzwelder HS (1990) Reduced sensitivity of the $N$-methyl-D-aspartate component of synaptic transmission to magnesium in hippocampal slices from immature rats. Dev Brain Res 56:257-262.

Nawy S, Jahr CE (1990) Time-dependent reduction of glutamate current in retinal bipolar cells. Neurosci Lett 108:279-283.

Okazaki MM, McNamara JO, Nadler JV (1989) $N$-methyl-D-aspartate receptor autoradiography in rat brain after angular bundle kindling. Brain Res 482:359-364.

Peterson DW, Collins JF, Bradford HF (1983) The kindled amygdala model of epilepsy: anticonvulsant action of amino acid antagonists. Brain Res 275:169-172.

Press WH, Flannery BP, Teukolsky SA, Vetterlin WT (1988) Numerical recipes in $\mathrm{C}$. The art of scientific computing. Cambridge: Cambridge UP.

Pusch M, Neher E (1988) Rates of diffusional exchange between small cells and a measuring patch pipette. Pfluegers Arch 411:204-211.

Racine RJ (1972) Modification of seizure activity by electrical stimulation. II. Motor seizure. Electroencephalogr Clin Neurophysiol 32: 281-294.

Sah P, Hestrin S, Nicoll RA (1989) Tonic activation of NMDA receptors by ambient glutamate enhances excitability of neurons. Science 246:815-818.

Sakmann B, Witzemann V, Brenner H (1992) Developmental changes in acetylcholine receptor structure and function as a model of synaptic plasticity. In: Fidia Research Foundation neuroscience award lectures, Vol 6, pp 53-103. New York: Raven.

Sigworth FJ, Sine SM (1987) Data transformations for improved display and fitting of single-channel dwell time histograms. Biophys $J$ 52:1047-1054.

Smith DO, Franke C, Rosenheimer JL, Zufall F, Hatt H (1991) Glutamate-activated channels in adult rat ventral spinal cord cells. J Neurophysiol 66:369-378.

Spitzer KW, Bridge IHB (1989) A simple device for rapidly exchanging solution surrounding a single cardiac cell. Am J Physiol 256:C441C447.

Stelzer A, Kay AR, Wong RKS (1988) GABA $_{\mathrm{A}}$-receptor function in hippocampal cells is maintained by phosphorylation factors. Science 241:339-341.

Urban L, Aitken PG, Friedman A, Somjen GG (1990) An NMDAmediated component of excitatory synaptic input to dentate granule 
cells in 'epileptic' human hippocampus studied in vitro. Brain Res 515:319-322.

Vezzani A, Wu H-Q, Moneta E, Samanin R (1988) Role of the $N$-methyl-D-aspartate-type receptors in the development and maintenance of hippocampal kindling in rats. Neurosci Lett 87:63-68.

Vyklicky L Jr, Benveniste M, Mayer ML (1990) Modulation of $N$-methyl-D-aspartic acid receptor desensitization by glycine in mouse cultured hippocampal neurones. J Physiol (Lond) 428:313-331.

Wang L-Y, Salter MW, MacDonald JF (1991) Regulation of kainate receptors by cAMP-dependent protein kinase and phosphatases. Science 253:1132-1135.

Wong EHF, Kemp JA (1991) Sites for antagonism on the $N$-methylD-aspartate receptor channel complex. Annu Rev Pharmacol Toxicol 31:401-425.
Woodhull AM (1973) Ionic blockage of sodium channels in nerve. J Gen Physiol 61:687-708.

Xie X, Berger TW, Barrionuevo G (1992) Isolated NMDA receptormediated synaptic responses express both LTP and LTD. J Neurophysiol 67:1009-1013.

Yamazaki M, Mori H, Araki K, Mori KJ, Mishina M (1992) Cloning, expression and modulation of a mouse NMDA receptor subunit. FEBS Lett 300:39-45.

Yeh GC, Bonhaus DW, Nadler JV, McNamara JO (1989) $N$-methylD-aspartate receptor plasticity in kindling: quantitative and qualitative alterations in the $N$-methyl-D-aspartate receptor-channel complex. Proc Natl Acad Sci USA 86:8157-8160. 